\title{
Worker Power and Class Polarization in Intra-Year Work Hour Volatility
}

\author{
Joe LaBriola \\ UC Berkeley \\ Department of Sociology \\ Daniel Schneider \\ UC Berkeley \\ Department of Sociology*
}

*Joe LaBriola (Corresponding author): UC Berkeley, Department of Sociology, 366 Barrows Hall, Berkeley, CA 94720; joelabriola@berkeley.edu. We are grateful for helpful feedback from Ryan Finnigan, Kristen Harknett, and seminar audiences at UC Berkeley. We thank Sarah Flood and Jose Pacas for providing clarifying information about longitudinal weights created by IPUMS to link individuals across CPS survey months. A previous version of this manuscript was presented at the 2018 American Sociological Association Annual Meeting. LaBriola thanks the National Science Foundation Graduate Research Fellowship Program (Award No. 1752814) and NICHD grant T32-HD007275 for research support. 


\title{
Worker Power and Class Polarization in Intra-year Work Hour Volatility
}

\begin{abstract}
Precarious work, which has become more prevalent in the United States in recent decades, is disproportionately experienced by workers of lower socio-economic classes, and research suggests that the erosion of worker power has contributed to this class polarization in precarity. One dimension of precarious work of growing interest to scholars and policymakers is instability faced by workers in the amount and regularity of their work hours. However, we know little about the magnitude of month-to-month or week-to-week (intra-year) volatility in hours worked, the extent of class-based polarization in this measure of job quality, and whether worker power moderates this polarization. In this paper, we make novel use of the panel nature of the nationally-representative Current Population Survey (CPS) to estimate intra-year volatility in the actual hours respondents report working in the previous week across four consecutive survey months. Using this new measure, we then show that, net of demographic characteristics and controls for occupation and industry, low-wage workers experience disproportionately greater work hour volatility. Finally, we find evidence that reductions in marketplace bargaining power-as measured by higher state-level unemployment rates-increase wage- and education-based polarization in work hour volatility, while increases in associational power-as measured by union coverage-reduce wage-based polarization in work hour volatility.
\end{abstract}




\section{Introduction}

Precarious work is commonly thought to have become more prevalent in the United States since the 1970s. This precarity is multi-dimensional, characterized by low pay, few fringe benefits, short job tenure, and non-standard contractual relations (Kalleberg 2011). Job quality is also shaped by the timing, amount, and regularity of work hours. While attention to work hours has long focused on over-work (i.e., Schor 1992), on non-standard work hours (i.e., Presser 2003), or on employee flexibility (i.e., Galinsky et al. 2011), scholars have recently turned to documenting the prevalence of work hour volatility, in which the number of hours that employees are scheduled to work by their employers is inconsistent (Henly et al. 2006; Lambert 2008; Henly and Lambert 2014; Finnigan and Hale 2018).

This intra-year volatility appears to be the product of employer-driven unpredictable work scheduling practices such as limited advance notice, on-call scheduling, and shift cancellation (Schneider and Harknett 2019) that are the focus of public attention (e.g., Kantor 2014) and that have sparked recent local ordinances that regulate unstable and unpredictable work hours in cities such as Seattle, San Francisco, and New York (Wolfe et al. 2018). Further, within-year variation in work hours is of concern because exposure to intra-year work hour volatility appears to have significant negative effects on the health and wellbeing of workers and their families in several ways. First, workers with volatile schedules experience increased stress and fatigue, and may additionally find it more difficult to access medical care (Wood et al. 2013; Ben-Ishai et al. 2014). Second, volatility in hours worked leads to increased conflict between one's work and non-work lives more generally. Unpredictable schedules make it difficult to arrange non-work obligations in order to accommodate work schedules (e.g., Alexander and Haley-Lock 2015). This can lead to more work-family conflict (Henly and Lambert 2014), increased difficulties in accessing childcare (Carrillo et al. 2017), transportation, and further education (Ben-Ishai et al. 2014), and delayed starting of romantic relationships or marriage (Lewchuk et al. 2015). Third, volatility in hours worked harms workers economically. Work-hour variability is an important cause of income volatility (e.g., Morduch and Schneider 2014), which can leave workers vulnerable to negative income shocks when work hours are low and prevent workers from budgeting for the future. These direct economic effects may be compounded by the effect that volatility in hours worked can have on eligibility for public benefits programs like TANF, SNAP, and CCDF, for which participation is contingent on working a certain 
number of hours in a week (Henly et. al. 2006; Lambert et al. 2012; Henly and Lambert 2014; Ben-Ishai 2015).

However, our knowledge of the causes and contours of intra-year volatility in hours worked-that is, variation in work hours on a week-to-week or month-to-month basis - is incomplete. For one, while the broader literature on precarious work leads us to expect that work hour volatility is more likely to be experienced by workers with lower earnings and lower levels of educational attainment, we know little about whether the experience of intra-year work hour volatility is polarized by socioeconomic class. Additionally, research in economic sociology on the structural causes of the spread of precarious work (see Kalleberg and Vallas (2018) for a review) suggests that forces that reduce worker power would lead not just to increased work hour volatility but also to increased polarization in work hour volatility by socio-economic class. While recent research has found that worker power, as measured by favorable state-level economic conditions (Finnigan 2018) and union membership (Finnigan and Hale 2018), is related to a lower likelihood of self-reporting varying working hours, we know less about whether worker power moderates the degree of class-based polarization in work hour volatility.

In this paper, we fill this gap by using a novel and improved measure of intra-year work hour volatility that relies on the Current Population Survey (CPS). The CPS has a rotating panel design in which households that newly enter the survey are interviewed for four consecutive months, ignored for eight months, and then interviewed for four consecutive months again. While most prior research using nationally-representative surveys has relied on questions in the CPS and the Survey of Income and Program Participation (SIPP) about usual work hours, we instead link respondent interviews and examine respondent self-reports of actual hours worked in the week preceding each monthly interview to generate a measure of actual volatility in hours worked over each set of four consecutive interview months. This new measure has the benefit of providing greater quantitative detail about the degree of intra-year work hour volatility that workers actually experience than has been available in previous measures.

We first use this measure to characterize intra-year work hour volatility. Second, we test the expectation that work hour volatility is polarized by socio-economic class, as measured by the wages and educational attainment of workers. Finally, we examine how two different forms of worker power- marketplace bargaining power, as measured by the tightness of state-level labor markets, 
and associational power, as captured by union coverage-shapes polarization in intra-year work hour volatility.

We document that a majority of workers experience some intra-year work hour volatility, with a significant portion of workers experiencing quite substantial work hour volatility. We also show that less-educated and lower-earning workers are more likely to experience this volatility. Finally, we find that lower state-level unemployment rates and union coverage are associated with less class-based polarization in work hour volatility.

\section{Precarity and Polarization}

By many measures, employment has become more precarious in the United States over the past several decades. Workers are now less likely to receive employer-provided health insurance (Mishel et al. 2009) and defined benefit pension plans (Shuey and O'Rand 2004), non-standard employment contracts are more common (Weil 2014), and many workers have non-standard (Presser 2003) and inflexible work schedules (Kelly and Moen 2007).

On the one hand, it is tempting to see precarity as the new normal, as the defining condition of contemporary capitalism (Giddens 1991; Bourdieu 1998; Bauman 2000). Yet, while work appears to have become more precarious generally over the past several decades, these transformations appear to have been particularly pronounced for workers of lower socio-economic classes (Kalleberg 2011; Fligstein and Shin 2004). This polarization of the labor market is evident in the growing inequality of wages (e.g., McCall and Percheski 2010) as well as in widening gaps between more highly educated and less educated workers in terms of access to fringe benefits and paid time off (Farber and Levy 2000; Glynn et al. 2016).

Research by economic sociologists and labor and managerial economists has identified several structural causes of increased work precarity for lower- and middle-class workers: financialization and the spread of the shareholder value conception of the corporation (e.g., Fligstein and Shin 2007, Tomaskovic-Devey and Lin 2011), globalization and the accelerated mobility of capital to low-wage countries (e.g., Bronfenbrenner and Luce 2004), the digital revolution (e.g., Brynjolfsson and McAfee 2014), slack labor markets (e.g., Wallace and Kwak 2018), and deunionization (e.g., Western and Rosenfeld 2011). One commonality across these factors is that each reduces the power 
that workers have in the employee-employer relationship.

Following Erik Olin Wright (2000:962), we can conceive of two forms of workers' bargaining power. The first form, structural power, comes from workers' position in the economic system. Within structural power, we focus in particular on marketplace bargaining power, which stems for workers operating in a tight labor market (Silver 2003). When workers lose marketplace bargaining power, as during an economic recession, employers have more power to reduce wages and other measures of job quality, because the pool of replacement workers is larger during slack labor markets. The second form, associational power, results from workers' collective organization through unions or political parties. In the United States, the reduction of workers' associational power has chiefly come through deunionization, which has reduced the ability of workers to effectively bargain for better working conditions (Rosenfeld 2014). Together, the erosion of marketplace bargaining power or associational power may enable employers to effectively transfer risk from the firm to the household by adopting more precarious labor policies (Hacker 2006).

\section{Intra-Year Work Hour Volatility}

Precarious employment is characterized by an economic dimension, evident in wages and fringe benefits, as well as a temporal dimension. While this temporal dimension is often captured with reference to workers' schedule control and to non-standard schedules, scheduling instability and insecurity is also increasingly recognized as a key indicator of this aspect of precarious employment. In particular, scholars have also pointed to the importance of volatility in the number of hours that employees are scheduled to work from week to week or month to month (that is, intra-year).

Recent scholarship suggests that this within-job intra-year work hour volatility is caused in part by "just-in-time" human resource management practices, which firms have implemented in order to minimize labor costs and effectively transfer payroll risk once borne by the firm to individual economic risk borne by workers and their households (Houseman 2001; Hacker 2006; Lambert 2008; Schneider and Harknett 2019). As part of these scheduling practices, employers may ask employees to work on call, schedule workers for different numbers of hours each week, cancel their employees' scheduled work shifts in the hours before their shifts start or even after they have arrived at work, or ask employees to start earlier or stay later than initially scheduled (Lambert 2008; Lambert 
et al. 2012; Alexander and Haley-Lock 2015; Halpin 2015). These practices appear to result in substantial work hour variation for employees, even conditional on being consistently employed at the same employer and net of any employee-driven variability stemming from care or other personal obligations (Lambert et al. 2014; Schneider and Harknett 2019).

Prior quantitative research has primarily relied on three large-scale national data sets to examine intra-year work hour volatility. First, scholars have used the National Longitudinal Survey of Youth 1997 Cohort (NLSY97), a nationally representative survey of people born between 1980 and 1984 who were living in the United States as of 1997. Since 2011, the NLSY97 has asked respondents the greatest number of hours they have worked in a week in the previous month, as well as the fewest number of hours they have worked in a week in the previous month. Lambert et al. (2014) use these questions to estimate intra-year work hour volatility, and find that hourly part-time workers and workers in the occupations of food service, retail, home care, and arts and media experience the highest intra-year work hour volatility. However, the NLSY97 is not an ideal source to measure intra-year work hour volatility because the data are limited to those in the NLSY97 birth cohort (1980-84) and because we can only examine trends in the NLSY97 since 2011.

The second data source that researchers have used to study the national prevalence of intra-year volatility in hours worked is the CPS (e.g., Golden 2001; Alexander and Haley-Lock 2015). Since 1994, the CPS has allowed respondents to say that their usual weekly work hours (as distinct from actual hours in the previous week) varied, instead of providing a numerical estimate. The share of workers selecting this option was constant at about 6\% from 1994-2002 (Kuhn and Lozano 2008), and Alexander and Haley-Lock (2015) report that the percentage of respondents who report that their usual work hours vary has remained relatively constant over the longer period 1994 to 2013, though the percentage of service workers who report that their usual hours vary has nearly doubled over this time (13\% in 1994 as compared to $25 \%$ in 2013).

Third, scholars have also drawn upon the SIPP, a continuous series of panel surveys of national households that contains information on income and labor force participation. Each household selected to participate in the SIPP is interviewed once every four months for approximately four years. As with the CPS, since 2004, the SIPP has allowed employed respondents to choose an "hours vary" option in response to a question about their usual weekly work hours in the time since their last interview. Finnigan and Hale (2018) find that a slightly higher percentage of workers in the 
$2004(7 \%)$ and $2008(10 \%)$ panels of the SIPP report that their usual weekly hours vary than in the CPS, which they attribute to the SIPP having a clearly-defined reference period for this response (the previous four months of work) while the CPS does not.

While the "hours vary" response sheds some light on national trends in volatility in hours worked, this measure has several important limitations. First, most workers whose hours vary will not choose this response unless specifically prompted (Lambert et al. 2012; Lambert et al. 2014). Lambert et al. (2014) conducted an experiment in which retail employees were randomly assigned to receive either the question "How many hours do you typically work each week?" or one that continued with "or do your hours vary too much to say?", and find that over twelve times as many retail workers will report that their hours vary under the second response. This suggests that the "hours vary" measure widely underestimates the percentage of workers who experience work hour volatility, because many respondents will not think to state that their hours vary in response to a question about usual work hours unless they are aware that this is an acceptable response. Second, it appears that reporting that usual "hours vary" is strongly positively associated with desirable schedule flexibility (Golden 2001), implying that the measure may capture a qualitatively different experience than the schedule volatility and lack of control discussed in the literature on precarious work. Finally, there is no way to quantify from this response alone exactly how much workers' hours vary. In sum, previous measures of intra-year work hour volatility are lacking, either because they do not cover the entire population of U.S. workers and can only be calculated for a short period of time (as in the NLSY97), or because they rely on a discrete indicator that likely underestimates the percentage of workers who experience work hour volatility and fails to capture the degree to which workers have volatile schedules (as in the CPS and SIPP).

\section{Polarization in Work Hour Volatility}

Just as prior research has shown evidence of polarization of many aspects of job quality, there is good reason to expect similar polarization in the experience of within-job intra-year work hour volatility. To the extent that dimensions of job quality within jobs tend to be positively correlated (Tilly 1997:269), class polarization in dimensions of job quality like wages and fringe benefits may imply that work hour volatility is increasingly likely to be experienced by workers with low levels of education and earnings. 
Suggestive empirical evidence for such polarization comes from the observation that precarious scheduling practices appear common for lower-class workers (Henly and Lambert 2014; Schneider and Harknett 2019). Qualitative research has documented that low-wage workers in the fields of health care (Clawson and Gerstel 2014), catering (Halpin 2015), retail and fast food (Carrillo et al. 2017), general merchandise (Vargas 2017), and retail apparel (Misra and Walters 2016; Van Oort 2018) are subjected to practices that include, on the one hand, canceling shifts at the last minute or sending workers home early, and, on the other hand, asking workers to stay after their shifts or requiring workers to be "on-call" to come in when more workers are needed. In the world of catering, Halpin (2015:420) describes how management used last minute changes and over-scheduling to closely align staffing with demand, saving payroll costs for employers while leaving workers in "limbo with respect to their ability to predict hours of work". In retail apparel, workers similarly contended with short-advance notice and variable hours, against a backdrop of low-wages and hours scarcity (Misra and Walters 2016). In a particularly clear example, Williams and Connell (2010:361) describe how one respondent experienced work hour fluctuation of 9 to 32 hours per week in the context of effectively "random scheduling". Across these low-wage jobs, the clear driver of work hours volatility is employer-driven scheduling practices.

However, while this research details precarious scheduling in low-wage sectors, it is, by sample design, largely silent on the question of work hour volatility in other quarters of the workforce and thus cannot inform an estimate of polarization in work hour volatility. While we may expect polarization on this dimension of job quality, it is also possible that we would not observe polarization in work hour volatility if workers in all socio-economic classes are experiencing unpredictable and unstable timing of work obligations, as firms increasingly restructure their employment arrangements around work projects rather than permanent, stable jobs (Cornfield et al. 2001). Such a lack of polarization in work hour volatility could occur even through increasing access of salaried professional workers to desirable work hour flexibility in which workers retain autonomy and control over their schedules (i.e., Galinsky et al. 2011), which might be empirically indistinguishable from work-hour volatility that is employer driven (Lambert 2008). While several quantitative studies examine work hour variation in the broader work force (Golden 2001; Alexander and Haley-Lock 2015; Finnigan and Hale 2018; Finnigan 2018), these studies do not actually gauge the degree to which work hour volatility is polarized. 


\section{Worker Power and Polarization in Work Hour Volatility}

Some recent research has examined whether both of our measures of worker power of interestmarketplace bargaining power and associational power-affect work hour volatility. Finnigan (2018) compares reports of usual work hours varying between the 2004-2007 SIPP panel and the 20082012 SIPP Panel and finds an increase from 7\% to 10\% of hourly workers, an increase that was largely accounted for by deteriorating state-level macro-economic conditions. This suggests that marketplace bargaining power decreases work hour volatility. Similarly, Finnigan and Hale (2018) report that union members are less likely than non-union members to report varying working hours from week to week. Though Finnigan and Hale (2018) find that this difference is due to indirect benefits of unionization (i.e., higher wages, longer job tenure, and less part-time work), they also find that state-level unionization further reduces the likelihood of reporting varying working hours for union members. Overall, these results point towards the importance of associational power for restraining the prevalence of work hour volatility.

Yet, though the literature on the structural origins of precarious work suggests that the erosion of worker power is a central cause of increasing class-based polarization in job quality, no empirical work has tested whether marketplace bargaining power or associational power moderates intra-year work hour volatility. Marketplace bargaining power may affect polarization in work hour volatility. In slack labor markets, excess labor supply may allow employers to adopt precarious scheduling practices that reduce labor costs and transfer economic risks to their most marginal employees. This would be consistent with research showing that the Great Recession caused increases in the prevalence of highly precarious jobs (Wallace and Kwak 2018). On the other hand, slack labor markets may not necessarily lead to greater inequalities in intra-year work hour volatility between workers with higher and lower levels of education if they also lead to the educational 'upskilling' of occupations (Okun 1973), such that highly-educated workers are forced down the occupational ladder into less appealing jobs characterized by greater within-job work hour volatility. It is also possible that slack labor markets have a similar impact on within-job work hour volatility at highwage jobs as at low-wage jobs.

We may also expect that associational worker power may reduce polarization in work hour volatility by reducing volatility for lower- and middle-class workers. As Wright (2000:981) writes,

"as working-class associational power within production increases, capitalists' unilateral control over 
the labor process declines... [and] changes in the labor process need to be negotiated and bargained with representatives of workers rather than unilaterally imposed." Thus, associational power may allow lower- and middle-class workers to bargain for less volatile work schedules, leading to lower polarization in work hour volatility. Even if unions work to provide consistent scheduling for all workers, not just lower- and middle-class workers, this would still reduce class-based polarization in work hour volatility if lower-class workers otherwise experience more work hour volatility.

\section{Open Questions}

We advance the existing literature on intra-year work hour variability in three respects. First, we utilize the panel nature of the CPS to develop a new measure of intra-year work hour variability that allows us to characterize intra-year volatility in work-hours over a longer period (1995-2017) than is measured in previous research using the SIPP (2004-2013) or the NLSY-97 (2011-2016). Our measure, which relies on reports of actual hours worked, also captures substantially more variability than the reports from SIPP and CPS that rely on respondents selecting an "hours vary" response. We are further able to focus on a subsample of workers who work at the same job, and whose work hours are not affected by missing work for what the CPS terms "non-economic" reasons, throughout the four consecutive CPS survey months.

Second, we build on this improvement to test whether there are differences in the levels of intrayear work hour volatility experienced by workers of different socio-economic classes. Here, in line with research on polarization in job quality, we expect that:

Hypothesis \#1: Low-wage and less-educated workers will experience greater withinjob intra-year work hour volatility.

Third, we use these data to test whether class polarization in work hour volatility is affected by marketplace bargaining power, measured by state-level unemployment rates, and/or by associational power, measured by union coverage. Here, we expect that higher rates of unemployment will function to undermine worker power and increase polarization in work hour volatility, while union coverage will buttress worker power and reduce polarization in work hour volatility.

Hypothesis \#2a: Higher state-level unemployment rates will be associated with greater wage- and education-based polarization in within-job intra-year work hour volatility. 
Hypothesis \#2b: Union coverage will be associated with lower wage- and educationbased polarization in within-job intra-year work hour volatility.

\section{Data}

We measure volatility in hours worked using the CPS, a publicly available, nationally-representative survey of households that is primarily designed to collect information about the United States' labor force. We use data downloaded from the CPS-IPUMS database (Flood et al. 2014). Though most studies have treated the CPS like a cross-sectional survey, the CPS has a rotating panel design in which households that newly enter the survey are interviewed for four consecutive months, ignored for eight months, and then interviewed for four consecutive months again. We focus on work hour volatility over these four month periods, relying on a question to respondents about how many hours they worked in the previous week; this week, known as the 'reference week', is usually the calendar week containing the 12 th day of the month. We use the IPUMS-created variable CPSIDP to link individuals across CPS samples following the method of Drew Rivera et al. (2014). We further follow Madrian and Lefgren (2000) and validate these links based on values for age, sex, and race across consecutive survey months.

We focus our analysis on a subsample of CPS respondents who a) are employed across four consecutive survey months, b) do not change jobs across four consecutive survey months, and c) who do not miss work or work part-time (less than 35 hours) in any survey reference week for reasons that the CPS labels 'non-economic reasons': performing kin care or other family obligations, having an illness or medical limitation, taking maternity / paternity leave, attending school or training, performing civic or military duty, or taking time off for holiday or vacation. ${ }^{1}$ We include this last restriction in order to more closely capture employer-driven work hour volatility, instead of that caused by external obligations.

Finally, we delete observations in which labor force information is obtained by a proxy in one of the four consecutive survey months (as measured by the IPUMS-created variable LFPROXY), since there are significant differences in self-reports and proxy reports of hours worked in the reference week in the CPS (e.g., Boehm 1989). The final sample stretches from December 1995 to March

\footnotetext{
${ }^{1}$ This subsample does include workers who are working part-time for economic reasons, which include: slack in the amount of available work, seasonal changes in demand, that part-time work was all that could be found, and that a full-time work week for the job is less than 35 hours of work.
} 
2017 and consists of 431,436 observations.

\section{Intra-year Work Hour Volatility}

For each four-month period in which respondents are interviewed, we measure the within-job intrayear work hour volatility as the coefficient of variation $(\mathrm{CV})$ of the hours the respondent reported working in the reference week. The CV is calculated as the corrected sample standard deviation of hours worked in each reference week, divided by the mean of hours worked in each reference week. This measure has been used in previous research on the prevalence of intra-year income volatility (Bania and Leete 2009; Morris et al. 2015), and has the benefit of being both scale invariant (that is, independent of the mean hours worked in each reference week) and directly proportionate to increases in the variation of hours worked. ${ }^{2}$

We test the construct validity of our measure of intra-year work hour volatility by comparing it to two other measures from the CPS: a binary measure from the 1997, 2001, and 2004 Work Schedules Supplements that indicates whether a worker reports that they have an irregular schedule arranged by their employer, and a binary variable indicating whether a worker reports that their "hours vary" in response to a question about their usual work hours. In Appendix Table 2, we report the results of two linear regressions that examine the relationship between the coefficient of variation of actual hours worked in four consecutive survey months and these other measures of work hour volatility, controlling for a categorical variable for year of the last survey month. These results show that the coefficient of variation is positively related to having an employer-set irregular schedule (though not significantly, likely due to the small sample size), and also significantly and substantively related to reporting that their "hours vary". Our new measure is thus consistent with these previous measures, while having the additional benefit of providing a more granular measure of work hour volatility than has been previously available.

We also test for the extent to which our measure of intra-year work hour volatility captures voluntary as opposed to involuntary work hour volatility using a question in the 1997, 2001, and 2004 Work Schedules Supplements that asks workers whether they can vary when they start and/or

\footnotetext{
${ }^{2}$ We also test the robustness of the results we find using the CV, which is a measure of work hour volatility that is relative to the number of hours worked, to using the standard deviation of hours worked, which is an absolute measure of work hour volatility. We find substantively similar results in both cases and focus on the CV in the rest of the paper. Appendix Table 1 contains the results of our models where the dependent variable is the standard deviation of hours worked.
} 
end work. About $30 \%$ of workers in these supplements reported that they are able to vary their starting and/or ending times, suggesting that, for a majority of workers, our measure of work hour volatility does not reflect voluntary scheduling flexibility. Appendix Table 3 compares our new measure of work hour volatility for workers in these supplements who are and are not able to vary when the timing of their work shifts. While we see that workers who are able to vary when they start and/or end work do experience more work hour volatility on average, these tables reveal a similar distribution of work hour volatility within each group and illustrate that there is much greater variation in work hour volatility within these groups than between them. These results suggest that our measure of intra-year work hour volatility is not primarily capturing voluntary work hour volatility.

\section{Socio-economic Class}

We examine if intra-year work hour volatility differs by two measures of respondent socio-economic class. First, we estimate respondents' hourly wages. CPS respondents who are paid hourly at the time of their fourth consecutive monthly interview report their hourly wages. For respondents who do not report their hourly wages, we estimate their hourly wages by dividing respondent reports from the same interview of how much they earn per week by how many hours they usually work per week. We then adjust these estimated hourly wages for inflation and categorize respondents in wage quartiles. Second, we measure respondent educational attainment and categorize respondents as either having less than a high school diploma, having a high school degree or some college without having attained a four-year degree, or having a Bachelor's degree or more education.

\section{Marketplace Bargaining Power}

We measure marketplace bargaining power at the state-level-the most detailed geographic area available for all CPS respondents-using the average of the monthly unemployment rate across the four consecutive months the respondent is surveyed. State-level unemployment rates are collected from the Bureau of Labor Statistics.

\section{Associational Worker Power}

We measure associational worker power using a binary variable indicating whether or not a worker is covered by a union, regardless of whether or not they are a union member. We theorize that 
union coverage is more indicative of associational worker power because workers who are covered by unions but not members are still likely to realize the benefits of their workplace union. However, we also test the robustness of our results to measuring associational worker power through union membership as well as through industry-specific regional union coverage, which may capture the presence of prevailing norms of equity that shape workplace conditions in the industry (Western and Rosenfeld 2011). We describe the creation of this latter variable in Appendix A.

Figure 1 plots state-level unemployment rates (in green box plots, on the left axis) and national union coverage rates (in orange, on the right axis) between 1995 and 2017. Both series are collected from the Bureau of Labor Statistics. We observe significant variation in unemployment rates both across time as well as between states in the same year. Meanwhile, union coverage rates drop relatively steadily over the sampled time frame.

\section{Controls}

We control for several demographic attributes in the CPS: age $(<30,30-39,40-49$, or $50+)$, race (White only, Black only, or other), sex (male or female), nativity (an indicator for being foreignborn), marital status (married or unmarried), and a categorical variable for the number of household children $(0,1,2$, or $3+)$. We also include indicators for broad industry and occupational classifications (reported in greater detail in Appendix A).

\section{Weights}

We create weights for our analysis that are based on the CPS earnings weight (EARNWT), which is recommended for use in analyses involving respondents' hourly wage and/or weekly earnings. We augment these weights in several ways, which we discuss briefly here and in greater detail in Appendix B. First, we account for attrition between the four consecutive survey months by weighting the sample of those who respond to four consecutive monthly surveys based on the population counts of CPS respondents in the first monthly survey. Next, to account for any possible relationship between the likelihood of being in our restricted sample (that is, working at the same job across four consecutive survey months and not missing work or working part-time for "non-economic reasons") and work hour volatility, we weight our restricted sample to have the same characteristics as the set of all workers in the labor force. Finally, because respondents who self-report their labor force 
information may systematically differ from those who do not, we weight the final sample of workers who self-report their labor force information in all four consecutive monthly surveys to have the same characteristics as all workers in the restricted sample. We use this final weight in all analyses.

\section{Analysis}

We begin by reporting descriptive statistics for the coefficient of variation and by presenting a number of illustrative simulations that show how various constellations of work hour reports might generate CVs at the sample mean, as well as at the 25th, 50th, 75th, 90th, and 95th percentiles. For ease of comparison, each set of reported hours worked has a mean of 40 hours worked per week.

\section{Polarization in Work Hour Volatility}

Then, we graphically examine trends in intra-year work hour volatility from 1995 to 2017 by wage quartile and education, in order to see whether low-wage and less-educated workers experience more work hour volatility and whether class-based polarization in work hour volatility has changed over time. Appendix C describes the creation of these graphs in greater detail.

Next, we estimate linear regression equations that examine the relationship between respondent class and work hour volatility, net of the measures of worker power and of other controls. Formally, we predict the coefficient of variation of respondent $i$ living in state $s$ at time $t$ :

$$
C V_{i}=\beta_{0}+\beta_{1} \text { Wage }_{i}+\beta_{2} E d_{i}+\beta_{3} Z_{i}+\gamma_{s}+\theta_{t}+\delta_{t}+\epsilon_{i s t}
$$

Here, $C V_{i}$ is the coefficient of variation of the respondent's actual hours worked over the four consecutive survey months (standardized so that the mean CV in the final sample equals 100), Wage $_{i}$ is a categorical variable for wage quartile (with the second wage quartile used as the reference group), $E d_{i}$ is a categorical variable for educational attainment (with a reference group of having a high school degree but not a Bachelor's degree), $Z_{i}$ is a vector of controls (including union coverage and state-level unemployment rate), $\gamma_{s}$ is a set of state indicators, and $\theta_{t}$ and $\delta_{t}$ are sets of indicators for the year and month of the last CPS survey. If Hypothesis \#1-that workers with low wages and low levels of education experience greater work hour volatility-is accurate, then we should see that $\beta_{1}$ should be positive and significant for respondents in the bottom wage quartile, and $\beta_{2}$ should be positive and significant for respondents with less than a HS degree. 


\section{Worker Power and Polarization in Work Hour Volatility}

Finally, we modify the above equation to test Hypothesis \#2b-that state-level unemployment rates exacerbate class gaps in work hour volatility:

$$
\begin{gathered}
C V_{i}=\beta_{0}+\beta_{1} \text { Wage }_{i}+\beta_{2} E d_{i}+\beta_{3} U R_{s t}+\beta_{4} W_{\text {age }} \times U R_{s t}+\beta_{5} E d_{i} \times U R_{s t}+ \\
\beta_{6} Z_{i}+\gamma_{s}+\theta_{t}+\delta_{t}+\epsilon_{i s t} .
\end{gathered}
$$

and to test Hypothesis \#2b-that union coverage reduces class gaps in work hour volatility:

$$
\begin{gathered}
C V_{i}=\beta_{0}+\beta_{1} \text { Wage }_{i}+\beta_{2} E d_{i}+\beta_{3} \text { Union }_{i}+\beta_{4} \text { Wage }_{i} \times \text { Union }_{i}+\beta_{5} E d_{i} \times \text { Union }_{i}+ \\
\beta_{6} Z_{i}+\gamma_{s}+\theta_{t}+\delta_{t}+\epsilon_{i s t},
\end{gathered}
$$

Here, $U R_{s t}$ is the average monthly unemployment rate in the respondent's state over the four survey months, Union $_{i}$ indicates whether a respondent is covered by a union, and all other variables are defined as above. We follow the advice of Balli and Sorenson (2013) on interaction terms in fixed-effects models and demean the state-level unemployment rate, union coverage, wage quartile, and educational attainment variables before creating the interaction terms. If Hypothesis \#2a is accurate, the estimates of $\beta_{4}$ and $\beta_{5}$ in Equation 2 should be positive and significant for respondents with low wages and levels of education, respectively, and vice versa for respondents with high wages and levels of education. Conversely, if Hypothesis $\# 2 \mathrm{~b}$ is accurate, then the estimates of $\beta_{4}$ and $\beta_{5}$ in Equation 3 should be negative and significant for respondents with low wages and levels of education, respectively, and vice versa.

In all regression models, we adjust standard errors for clustering both within states and within respondents, since respondents who are interviewed for all eight months in the CPS sample are observed twice in our data. ${ }^{3}$

\section{Results}

\section{Intra-year Work Hour Volatility}

In order to give a sense of what intra-year work hour volatility looks like across the distribution of the CV, Table 1 displays the mean and 25th, 50th, 75th, 90th, and 95th percentiles of the CV among workers in our sample, along with hypothetical sets of reported hours worked in the previous week

\footnotetext{
${ }^{3}$ We use the reghdfe package in Stata (Correia 2017) to implement two-way clustering.
} 
across four consecutive monthly surveys for each statistic. Each hypothetical set of reported weekly hours worked has a mean of 40 hours per week. $33 \%$ of workers report no work hour volatility across four consecutive CPS survey months. The median worker in our sample has a CV of weekly hours worked that is similar to a full-time worker experiencing, roughly, a four-hour swing in weekly hours worked every week. Workers at the 75th percentile of intra-year work hour volatility experience over twice as much intra-year work hour volatility as those at the median, with workers at the 90th percentile experiencing nearly twice as much intra-year work hour volatility as those at the 75 th percentile. In sum, while about a third of workers experience little to no work hour volatility, Table 1 suggests that a significant proportion of workers see quite substantial variation in weekly hours worked.

\section{Polarization in Intra-year Work Hour Volatility}

We first present trends in within-job intra-year work hour volatility by wage quartile and educational attainment, as seen in Figures 2 and 3, respectively. These graphs show that workers with the lowest wages and lowest levels of education experience much more intra-year work hour volatility than do other workers. Workers in the top three wage quintiles appear to experience generally similar levels of work hour volatility, as do workers with a HS degree and workers with a Bachelor's degree or higher. The widest class gaps in intra-year work hour volatility, then, are between low-wage and less-educated workers and all other workers.

Notably, Figures 2 and 3 suggest that class gaps in intra-year work hour volatility grew sharply during the Great Recession. While workers of all wages and levels of educational attainment experienced an increase in work hour volatility during the Great Recession, the largest increases in volatility were among low-wage and less-educated workers. While class gaps in work hour volatility appear to have decreased somewhat in the years since the Great Recession, they do not appear to have returned to their pre-Recession levels.

Figures 2 and 3, taken by themselves, seem to support Hypothesis \#1-that low-wage and lesseducated workers experience more work hour volatility-and also hint towards a relationship between marketplace bargaining power and class polarization in work hour volatility in the direction suggested by Hypothesis \#2a. However, these figures do not account for differences in the demographic composition of workers by class, provide statistical support for either hypothesis, or speak towards 
the validity of Hypothesis \#2b-that associational bargaining power reduces class-based polarization in work hour volatility.

The first column of Table 2 presents coefficients of interest from the estimated linear regression model of Equation 1 above, which formally tests Hypothesis $\# 1 .{ }^{4}$ We find that respondents in the lowest wage quartile (compared to the second wage quartile) experience significantly more work hour volatility, controlling for all other factors, while workers above the second wage quartile experience less work hour volatility compared to workers in the workers in the second wage quartile. These wage-based gaps are substantively large. Because the dependent variable is scaled to 100, the regression coefficients imply that workers in the lowest wage quartile experience roughly $23 \%, 28 \%$, and $26 \%$ more work hour volatility than workers in the second, third, and highest wage quartiles, respectively, holding all other factors constant..$^{5}$

We also find that workers without a high school degree experience significantly more work hour volatility than workers with a high school degree but no Bachelor's. Yet, the magnitude of this coefficient is relatively small in comparison to the coefficient on low-wage work. Further, we find that, controlling for other factors, college-educated workers also experience more work hour volatility than workers with a high school degree but no Bachelor's. In sum, then, the results of Model \#1 reveal partial support for Hypothesis \#1. Low-wage workers experience significantly more work hour volatility than higher wage workers; meanwhile, while workers without a high school degree experience relatively high work hour volatility, so do workers with a Bachelor's degree.

Finally, we find the that state-level unemployment rate is positively associated with work hour volatility: a one percentage point increase in the unemployment rate is associated with roughly a one percent increase in the coefficient of variation. Somewhat surprisingly, we also find that workers who are covered by a union experience modestly higher levels of work hour volatility, net of other covariates.

\section{Worker Power and Polarization in Work Hour Volatility}

We now turn towards our tests of the association between worker power and reduced class-based polarization in work hour volatility. Model 2 (Equation 2 earlier) tests Hypothesis \#2a, which proposes that reductions in marketplace bargaining power-which we operationalize through the

\footnotetext{
${ }^{4}$ Appendix Table 4 contains the full results of models presented in Table 2.

${ }^{5}$ Marginal effect estimates reveal virtually identical results.
} 
state-level unemployment rate-lead to greater polarization in work hour volatility. Examining the interactions between the unemployment rate and respondent's measures of socio-economic class, we find evidence of significantly wider wage-based and education-based gaps in work hour volatility with higher state-level unemployment rates, driven by increased volatility for low-wage and lesseducated workers. Work hour volatility for low-wage workers is more strongly affected by rising unemployment than that of workers in the second wage quartile, while workers in the third wage quartile and highest wage quartile experience similar effects of changes in the unemployment rate as do workers in the second wage quartile. For low-wage workers, a one percentage point increase in the unemployment rate is associated with roughly a five percent increase in the coefficient of variation of weekly hours worked.

We find similar, though smaller, effects of state-level unemployment rates on education-based gaps in work hour volatility. The coefficient on the interaction between unemployment rate and having less than a HS degree (as compared to the reference of the interaction between unemployment rate and having a HS degree) is positive and significant. Meanwhile, the coefficient on the interaction between unemployment rate and having a Bachelor's degree (with the same reference group as above) is not significant. In sum, there is strong evidence to support Hypothesis \#2a-that higher state-level unemployment rates are associated with greater class-based polarization in intra-year work hour volatility, with this association solely driven by gaps between low-wage and less-educated workers and all other workers.

Next, we turn to Model 3 (Equation 3 earlier), which tests whether increases in associational power-measured by whether a worker is covered by a union or not-reduce class-based polarization in work hour volatility. We find strong evidence that, compared to workers in the second wage quartile, low-wage workers who are covered by a union experience significantly less work hour volatility than those who are not. In contrast, there is no significant difference in the estimated effect being in a union on work hour volatility for workers in the third and fourth wage quartiles as compared to workers in the second wage quartile. We also find no evidence that union coverage affects educational polarization in work hour volatility. We thus find partial support for Hypothesis \#2b: union coverage significantly reduces gaps in work hour volatility between low-wage workers and all other workers, but it does not affect education-based gaps in work hour volatility.

Appendix Table 5 reports results from regressions in which associational worker power is oper- 
ationalized by union membership and by industry-specific regional union coverage. We find that higher levels of each variable are associated with reductions in wage-based polarization in work hour volatility. Along with the results of Model 3, this provides strong evidence that associational worker power moderates wage-based polarization in work hour volatility.

Figure 4 shows marginal predictions from Model 2 of work hour volatility across various levels of unemployment rates, broken down by wage quartile and educational attainment, respectively. Here, the unemployment rate is centered at the mean in our sample, $6.1 \%$, with one standard deviation in the unemployment rate in our sample being equal to 2.04 percentage points. In these marginal plots, the coefficient of variation in hours worked is scaled to have a mean of 100 . We see that the effect of negative economic conditions on work hour volatility is most stark for workers in the lowest wage quartile. At an unemployment rate of $6.1 \%$, the average low-wage worker experiences roughly $20 \%$ more volatility than the sample average, while the average worker in other wage quartiles experiences slightly below-average volatility. However, as unemployment rises to two standard deviations above the mean (roughly 10.2\%), the average low-wage worker experiences nearly $40 \%$ more volatility than the sample average, while the work hour volatility of other workers is not affected much. The educational gradient in the effect of unemployment rates on work hour volatility is less stark. The work hour volatility of those without a high school education is most strongly affected by rising unemployment; however, the confidence intervals overlap at all measured levels of unemployment.

Finally, Figure 5 shows marginal predictions from Model 3 of work hour volatility for those who are and are not covered by a union, again by wage quartile and educational attainment. Among workers who are not covered by a union, low-wage workers experience significantly more work hour volatility. However, this gap markedly narrows among workers covered by a union: while the point estimate of estimated work hour volatility for low-wage workers covered by a union is higher than for higher-wage workers covered by a union, the confidence intervals of this estimate now overlap with those of higher-wage workers. When looking by educational attainment, we see little evidence that union coverage moderates work hour volatility. 


\section{Discussion}

Unpredictability and instability in the timing and regularity of work hours is a dimension of precarious work that is of increased interest to social scientists as well as the public. There is good reason to expect that, as with other dimensions of precarious work, the experience of work hour volatility is stratified by class, and that forces that reduce worker power would increase class-based polarization in work hour volatility. However, with several notable exceptions, little previous research has used nationally-representative data to measure the degree of work hour volatility that workers experience. Further, though previous qualitative research has documented the prevalence of unpredictable scheduling practices in low-wage jobs, we know little about whether low-wage and/or less-educated workers experience greater work hour volatility, or whether the degree of worker power does affect polarization in this dimension of precarious work.

In this paper, we use the Current Population Survey to develop a new measure of intra-year work hour volatility that is based on respondents' self-reports of actual hours worked in the previous week across four consecutive survey months. This measure is consistent with previously used measures of work hour volatility, while having the additional benefit of providing a more granular estimate of the magnitude of instability in workers' weekly hours. We then use this measure to examine the hypothesis that work hour volatility is polarized by worker socio-economic class. Finally, we use two measures of worker power-state-level unemployment rates to reflect marketplace bargaining power, and union coverage to reflect associational power-to test the hypothesis that reductions in worker power increase class-based polarization in work hour volatility.

We find that workers with low wages (though not workers with less education) experience higher levels of work hour volatility. Further, we find that wage- and education-based gaps in work hour volatility are wider when state-level unemployment rates are higher, and that wage-based gaps in work hour volatility are narrower among workers covered by unions. The effect of worker power on work hour volatility is most pronounced for low-wage workers. These results add to previous work that has shown that the employment of low-skilled workers is more sensitive to changing economic conditions (e.g., Blank 2009) and deunionization (e.g., Vidal 2013) than is the employment of higherskilled workers. Here, we show that, even among workers who remain employed, low-SES workers experience disproportionately larger increases in intra-year work hour volatility with falling worker 
power compared to other workers.

These results also suggest a fruitful extension of Wright (2000)'s model of the forms of workers' bargaining power. In this model, worker power stems from collective organization or tight labor markets, as well as from workers' strategic location within key industrial sectors. While this model does not consider the effect of workers' wage or education on the strength of worker power, we find that worker power appears to improve work hour volatility most for low-wage and less-educated workers. This finding accords more generally with the work of economic sociologists and labor economists who have shown that forces that reduce worker power have made work broadly more precarious for lower- and middle-class workers. Thus, we suggest that workers' wage and education may be theorized as key moderating forces which shape the effect of workers' bargaining power on job quality.

Our analysis reveals three other notable findings. First, as seen in Figure 1, is that the effect that the Great Recession had on widening class gaps in within-job intra-year work hour volatility appears to have persisted long after the end of the recession. This is consistent with other research that suggests that the Great Recession led to structural changes in the labor market that disproportionately affect workers with low human capital (Rothstein 2017). In this way, our research helps to answer the call of Redbird and Grusky (2016) to fill the gap in sociological knowledge on the distributional effects of the Great Recession.

Second is that the overall increase in intra-year work hour volatility was mostly confined to the period of the Great Recession. This is consistent with recent research that shows that the Great Recession led to an increase in the number of jobs characterized by high precarity (Wallace and Kwak 2018). However, we do not find evidence that work-hour instability has substantially increased over the full observation period, which parallels recent work by Bernhardt (2014) that finds limited evidence of an increase in non-standard work arrangements over time. We do not necessarily find this to be incompatible with other work that has documented a broader long-run increase in the precarious work (e.g., Kalleberg 2011). It is possible that work is becoming generally less precarious in the dimension of work hour volatility but more precarious in other dimensions: low pay, lower prospects of advancement within companies, shorter job tenures, and fewer workplace benefits.

Third, the full results of our regression models, presented in Appendix Table 4, show how work hour volatility varies by employment in various occupational and industry categories, net of 
other covariates. We use reference categories ("production" for occupation, and "transportation" for industry) in which work hour volatility is nearest the mean for the sample. Notably, we find that workers in the occupational categories of "personal care and service" and "food preparation and service" experience relatively higher work hour volatility, consistent with previous research documenting precarious scheduling practices in these occupations (Halpin 2015; Carrillo et al. 2017). However, in spite of other research describing inconsistent scheduling in retail jobs (Misra and Walters 2016; Vargas 2017; Van Oort 2018), we do not find significantly higher work hour volatility in the occupation of "sales" after controlling for wage, education, and other factors.

Our findings are subject to some important limitations. Perhaps most important is that we do not directly measure week-to-week volatility in hours worked, since we only observe one week per month. However, our measure does capture the sort of volatility in hours worked that would come from random weekly changes in a worker's schedule-similar to that which might come from the use of 'just-in-time' scheduling with especially variable customer demand. Further, our measure is more likely to capture discrete changes in the number of hours employees work per week that employers make in response to seasonal changes in demand than would a method that captures weekly volatility over a smaller time period.

Second, though Appendix Table 3 suggests that our measure of work hour volatility does not primarily capture voluntary work hour volatility, we do not directly observe the degree to which work hour volatility is voluntary and/or desirable as opposed to involuntary and/or undesirable. In general, we believe our finding that our measure of work hour volatility is higher-disproportionately so for low-wage and less-educated workers-when state-level unemployment rates are higher suggests that our measure of work hour volatility mainly reflects involuntary work hour volatility. This would be consistent with previous research suggesting that, in response to slack labor markets, employers (low-wage employers in particular) are more able to implement practices associated with precarious work (e.g., Wallace and Kwak 2018). In contrast, it is less clear that workers would be more likely to voluntarily vary their weekly work hours when state-level unemployment rates rise.

Third, and related to the second point, the CPS does not contain questions that allow us to specifically examine the relationship between employer-driven unpredictable work scheduling and our measure of work hour volatility. While there is good reason to suggest that employer-driven unpredictable work schedules is a key driver of the work hour volatility we observe in the CPS, it 
is possible, on the one hand, that workers could have unpredictable schedules from day-to-day but still have a relatively consistent number of hours from week to week, or, on the other hand, that workers could receive predictable schedules from employers but voluntarily build in volatility into their schedules. Future work would benefit from the collection of nationally-representative data that allows us to more accurately understand the relationship between the unpredictability of work schedules, workers' own desires for scheduling stability (or flexibility), and the experience of work hour volatility.

Despite these limitations, our methodology opens the doors to more detailed investigations into intra-year work hour volatility and precarious work more generally. For example, our measure of intra-year work hour volatility could be used to estimate the impact of future state-level worker scheduling laws that give workers more scheduling stability. Further, future research could concretely investigate the relationship between different facets of worker power and the prevalence of, and/or polarization in, other forms of precarious work. Finally, researchers could use data from the 2014 SIPP panels, which asks respondents what days of the week they work and when they start and end work, to investigate within-week (instead of between-week) work hour volatility. Such work could investigate whether this form of work hour volatility is also polarized by class, and whether measures of worker power moderate the degree of class polarization in within-week work hour volatility. 


\section{References}

Alexander, Charlotte and Anna Haley-Lock. 2015. "Underwork, Work-Hour Insecurity, and A New Approach to Wage and Hour Regulation." Industrial Relations. 54(4):695-716.

Balli, Hatice and Brent Sorenson. 2013. "Interaction Effects in Econometrics." Empirical Economics 45(1): 583-603.

Bania, Neil and Laura Leete. 2009. "Monthly household income volatility in the U.S., 1991/92 vs. 2002/03." Economics Bulletin. 29(3):2100-12.

Bauman, Zygmunt. 2000. Liquid Modernity. Cambridge: Polity Press.

Ben-Ishai, Liz, Sasha Hammad, and Christina Warden. 2014. "Tackling Unstable and Unpredictable Work Schedules." Center for Law and Social Policy, Retail Action Project, and Women Employed. (Online Link.)

Ben-Ishai, Liz. 2015. "Volatile Job Schedules and Access to Public Benefits." Center for Law and Social Policy.

Bernhardt, Annette. 2014. "Labor Standards and the Reorganization of Work: Gaps in Data and Research." IRLE Working Paper No. 100-14. (Online Link.)

Blank, Rebecca M. 2009. "Economic Change and the Structure of Opportunity for Less-Skilled Workers." P. 63-91 in Changing Poverty, Changing Policies, edited by Maria Cancian and Sheldon Danzinger. Russell Sage.

Boehm, Lawrence E. 1989. "Reliability of Proxy Response in the Current Population Survey." Proceedings of the Survey Research Methods Section, American Statistical Association. 486489. (Online Link.)

Bourdieu, Pierre. 1998. Acts of Resistance: Against the Tyranny of the Market. Translated by Richard Nice. Cambridge: Polity Press.

Bronfenbrenner, Kate and Stephanie Luce. 2004. The changing nature of global corporate restructuring: The impact of production shifts on jobs in the US, China, and around the globe. Washington, DC: US / China Economic and Security Review Commission.

Brynjolfsson, Erik and Andrew McAfee. 2014. The Second Machine Age: Work, Progress, and Prosperity in a Time of Brilliant Technologies. New York, NY: W.W. Norton \& Company.

Carillo, Dani, Kristen Harknett, Allison Logan, Sigrid Luhr, and Daniel Schneider. 2017. "Instability of Work and Care: How Work Schedules Shape Child-Care Arrangements for Parents Working in the Service Sector." Social Service Review. 91(3):422-455.

Clawson, Dan and Naomi Gerstel. 2014. Unequal Time: Gender, Class, and Family in Employment Schedules. New York, NY: Russell Sage Foundation.

Cornfield, Daniel, Karen Campbell, and Holly McCammon. 2001. Introduction to Working in Restructured Workplaces: Challenges and New Directions for the Sociology of Work. SAGE Publications. Thousand Oaks, CA.

Correia, Sergio. 2017. "reghdfe: Stata module for linear and instrumental-variable/GMM regression absorbing multiple levels of fixed effects." Statistical Software Components s457874, Boston College Department of Economics. (Online Link.)

Drew Rivera, Julia A., Sarah Flood, and John Robert Warren. 2014. "Making full use of the longitudinal design of the Current Population Survey: Methods for linking records across 16 months." Journal of Economic and Social Measurement. 121-44. 
Farber, Henry S. and Helen Levy. 2000. "Recent trends in employer-sponsored health insurance coverage: are bad jobs getting worse?" Journal of Health Economics. 19(1):93-119.

Finnigan, Ryan. 2018. "Varying weekly work hours and earnings instability in the Great Recession." Social Science Research. 74:96-107.

Finnigan, Ryan and Savannah Hunter. 2018. "Occupational Composition and Racial/Ethnic Inequality in Varying Work Hours in the Great Recession." Research in the Sociology of Work. (Online Link.)

Finnigan, Ryan and Jo Mhairi Hale. 2018. "Working 9 to 5? Union Membership and Work Hours and Schedules." Social Forces. 96(4):1541-68.

Fligstein, Neil and Taek-jin Shin. 2004. "The Shareholder Value Society: A Review of the Changes in Working Conditions and Inequality in the United States, 1976 to 2000." pp. 401-432 in Social Inequality. Ed. Kathryn Neckerman. New York: Russell Sage Foundation.

Fligstein, Neil and Taek-jin Shin. 2007. "Shareholder Value and the Transformation of the U.S. Economy, 1984-2000." Sociological Forum. 22(4):399-424.

Flood, Sarah, Miriam King, Steven Ruggles, and John Robert Warren. 2015. Integrated Public Use Microdata Series, Current Population Series: Version 4.0. [dataset]. Minneapolis: University of Minnesota. (Online Link.)

Galinsky, Ellen, Kelly Sakai, and Tyler Wigton. 2011. "Workplace flexibility: from research to action." The Future of Children. 21(2):141-61.

Giddens, Anthony. 1991. Modernity and Self-Identity: Self and Society in the Late Modern Age. Stanford, CA: Stanford University Press.

Glynn, Sarah Jane, Heather Boushey, and Peter Berg. 2016. "Who Gets Time Off? Predicting Access to Paid Leave and Workplace Flexibility." Report for the Center for American Progress. (Online Link.)

Golden, Lonnie. 2001. "Flexible Work Schedules: Which Workers Get Them?" American Behavioral Scientist. 44(7):1157-78.

Hacker, Jacob S. 2006. The Great Risk Shift: The New Economic Insecurity and the Decline of the American Dream. Oxford: Oxford University Press.

Halpin, Brian W. 2015. "Subject to Change Without Notice: Mock Schedules and Flexible Employment in the United States." Social Problems. 62(3):419-38.

Henly, Julia R., H. Luke Shaefer, and Elaine Waxman. 2006. "Nonstandard Work Schedules: Employer- and Employee-Driven Flexibility in Retail Jobs." Social Service Review. 80(4):60934.

Henly, Julia R. and Susan J. Lambert. 2014. "Unpredictable Work Timing in Retail Jobs: Implications for Employee Work-Life Conflict." Industrial \& Labor Relations Review. 67(3):986-1016.

Houseman, Susan N. 2001. "Why Employers Use Flexible Staffing Arrangements: Evidence from an Establishment Survey." Industrial \& Labor Relations Review. 55(1):149-70.

Kalleberg, Arne L. 2011. Good Jobs, Bad Jobs. New York: Russell Sage Foundation.

Kalleberg, Arne L. and Steven P. Vallas. 2018. "Probing Precarious Work: Theory, Research, and Politics." pp. 1-31 in Precarious Work (Research in the Sociology of Work, Volume 31). Eds. Arne L. Kalleberg and Steven P. Vallas. Emerald Publishing. 
Kantor, Jodi. 2014. "Working Anything but 9 to 5." The New York Times. August 13. (Online Link.)

Kelly, Erin L. and Phyllis Moen. 2007. "Rethinking the Clockwork of Work: Why Schedule Control May Pay Off at Work and at Home." Advances in Developing Human Resources. 9(4):487-506.

Kuhn, Peter and Fernando Lozano. 2008. "The Expanding Workweek? Understanding Trends in Long Work Hours among U.S. Men, 1979-2006." Journal of Labor Economics. 26(2):311-43.

Lambert, Susan J. 2008. "Passing the buck: Labor flexibility practices that transfer risk onto hourly workers." Human Relations. 61(9):1203-27.

Lambert, Susan J., Anna Haley-Lock, and Julia R. Henly. 2012. "Schedule flexibility in hourly jobs: unanticipated consequences and promising directions." Community, Work, and Family. 15(3):293-315.

Lambert, Susan J., Peter J. Fugiel, and Julia R. Henly. 2014. "Precarious Work Schedules among Early-Career Employees in the US: A National Snapshot." EINet research brief. (Online Link.)

Lewchuk, Wayne, Michellyn Lafleche, Stephanie Procyk, Charleye Cook, Diane Dyson, Luin Goldring, Karen Lior, Alan Meisner, John Shields, Anthony Tambureno, and Peter Viducis. 2015. "The Precarity Penalty." Poverty and Employment Precarity in Southern Ontario research brief.

Lin, Ken-Hou and Donald Tomaskovic-Devey. 2013. "Financialization and U.S. Income Inequality, 1970-2008." American Journal of Sociology. 118(5):1284-1329.

Madrian, Brigitte C. and Lars John Lefgren. 2000. "An Approach to Longitudinally Matching Current Population Survey (CPS) Respondents." Journal of Economic and Social Measurement. 26(1):31-62.

McCall, Leslie and Christine Percheski. 2010. "Income Inequality: New Trends and Research Directions." Annual Review of Sociology. 36:329-47.

Mishel, Lawrence, Jared Bernstein, and Heidi Shierholz. 2009. The State of Working America 2008/2009. Ithaca, NY: ILR Press.

Misra, Joya and Kyla Walters. 2016. "All Fun and Cool Clothes? Youth Workers' Consumer Identity in Clothing Retail." Work and Occupations. 43(3):294-325.

Morduch, Jonathan, and Rachel Schneider. 2014. "Spikes and Dips: How Income Uncertainty Affects Households." U.S. Financial Diaries.

Morris, Pamela A., Heather D. Hill, Lisa A. Gennetian, Chris Rodrigues, and Sharon Wolf. 2015. "Income Volatility in U.S. Households with Children: Another Growing Disparity between the Rich and Poor?" Institute for Research on Poverty Discussion Paper No. 1429-15.

Okun, Arthur. 1973. "Upward Mobility in a High-Pressure Economy." Brookings Papers on Economic Activity. 4(1):207-52.

Presser, Harriet B. 2003. Working in a 24/7 Economy: Challenges for American Families. New York, NY: Russell Sage Foundation.

Redbird, Beth and David B. Grusky. 2016. "Distributional Effects of the Great Recession: Where Has All the Sociology Gone?" Annual Review of Sociology. 42:185-215.

Rosenfeld, Jake. 2014. What Unions No Longer Do. Cambridge, MA: Harvard University Press.

Rothstein, Jesse. 2017. "The Great Recession and Its Aftermath: What Role for Structural Changes?" RSF: The Russell Sage Foundation Journal of the Social Sciences. 3(3):22-49. 
Schneider, Daniel and Kristen Harknett. 2017. "Income Volatility in the Service Sector: Contours, Causes, and Consequences." Research brief for the Aspen Institute's Expanding Prosperity Impact Collaborative. (Online Link.)

Schneider, Daniel and Kristen. Harknett. 2019. "Consequences of Routine Work-Schedule Instability for Worker Health and Well-Being." American Sociological Review.

Schor, Juliet. 1992. The Overworked American: The Unexpected Decline of Leisure. New York, NY: Basic Books.

Shuey, Kim M. and Angela M. O'Rand. 2004. "New Risks for Workers: Pensions, Labor Markets, and Gender." Annual Review of Sociology. 30:453-477.

Tomaskovic-Devey, Donald and Ken-Hou Lin. 2011. "Income Dynamics, Economic Rents, and the Financialization of the U.S. Economy." American Sociological Review. 76(4):538-559.

Tilly, Charles. 1997. Durable Inequality. Berkeley, CA: University of California Press.

Van Oort, Madison. 2018. "The Emotional Labor of Surveillance: Digital Control in Fast Fashion Retail." Critical Sociology. (Online Link to Pre-print.)

Vargas, Tracy. 2017. "Employees or Suspects? Surveillance and Scrutinization of Low-Wage Service Workers in U.S. Dollar Stores." Journal of Labor and Society 20: 207-230.

Vidal, Matt. 2013. "Inequality and the Growth of Bad Jobs." Contexts. 12(4):70-72.

Wallace, Michael and Joonghyun Kwak. 2018. "Bad Jobs in a Troubled Economy: The Impact of the Great Recession in America's Major Metropolitan Areas." pp. 125-155 in Precarious Work (Research in the Sociology of Work, Volume 31). Eds. Arne L. Kalleberg and Steven P. Vallas. Emerald Publishing.

Weil, David. 2014. The Fissured Workplace: Why Work Became So Bad for So Many and What Can Be Done to Improve It. Cambridge, MA: Harvard University Press.

Western, Bruce and Jake Rosenfeld. 2011. "Unions, Norms, and the Rise in US Wage Inequality." American Sociological Review. 76(4):513-537.

Williams, Christine L. and Catherine Connell. 2010. "'Looking Good and Sounding Right": Aesthetic Labor and Social Inequality in the Retail Industry." Work and Occupations. 37(3):349377 .

Wolfe, Julia, Janelle Jones, and David Cooper. 2018. "Fair workweek" Laws Help more than 1.8 Million Workers. Washington D.C.: Economic Policy Institute report.

Wood, Stephen, George Michaelides, and Peter Totterdell. 2013. "The Impact of Fluctuating Workloads on Well-Being and the Mediating Role of Work-Nonwork Interference in This Relationship." Journal of Occupational Health Psychology. 18(1):106-19. 
Table 1. Distribution of the CV of Weekly Hours Worked

\begin{tabular}{lrrrrr}
\hline \hline & \multicolumn{5}{c}{ Hypothetical Weekly Hours Worked } \\
\cline { 3 - 6 } & CV & Month 1 & Month 2 & Month 3 & Month 4 \\
\hline - Mean & .087 & 37 & 43 & 37 & 43 \\
25th percentile & 0 & 40 & 40 & 40 & 40 \\
50th percentile & .060 & 38.5 & 42.5 & 37.5 & 41.5 \\
75th percentile & .122 & 40 & 34 & 40 & 46 \\
90th percentile & .217 & 32.5 & 47.5 & 32.5 & 47.5 \\
95th percentile & .293 & 48 & 24 & 49.5 & 38.5 \\
\hline
\end{tabular}


Table 2: Regression Results from Models Predicting the CV of Weekly Hours Worked

\begin{tabular}{|c|c|c|c|}
\hline & (1) & $(2)$ & $(3)$ \\
\hline Lowest wage quartile & $\begin{array}{c}23.11^{* * *} \\
(1.688)\end{array}$ & $\begin{array}{c}23.27^{* * *} \\
(1.707)\end{array}$ & $\begin{array}{c}22.58^{* * *} \\
(1.754)\end{array}$ \\
\hline Second wage quartile & ref. & ref. & ref. \\
\hline Third wage quartile & $\begin{array}{c}-5.354^{* * *} \\
(0.832)\end{array}$ & $\begin{array}{c}-5.336^{* * *} \\
(0.840)\end{array}$ & $\begin{array}{c}-5.473^{* * *} \\
(0.817)\end{array}$ \\
\hline Highest wage quartile & $\begin{array}{c}-2.284^{+} \\
(1.301)\end{array}$ & $\begin{array}{l}-2.005 \\
(1.286)\end{array}$ & $\begin{array}{r}-2.550^{+} \\
(1.316)\end{array}$ \\
\hline Less than HS & $\begin{array}{c}6.449^{* * *} \\
(1.783)\end{array}$ & $\begin{array}{c}6.985^{* * *} \\
(1.775)\end{array}$ & $\begin{array}{c}6.395^{* * *} \\
(1.806)\end{array}$ \\
\hline HS, no BA & ref. & ref. & ref. \\
\hline BA or higher & $\begin{array}{c}8.578^{* * *} \\
(0.830)\end{array}$ & $\begin{array}{c}8.696^{* * *} \\
(0.850)\end{array}$ & $\begin{array}{c}8.613^{* * *} \\
(0.843)\end{array}$ \\
\hline Unemployment rate & $\begin{array}{l}1.342^{* *} \\
(0.468)\end{array}$ & $\begin{array}{l}1.400^{* *} \\
(0.463)\end{array}$ & $\begin{array}{l}1.348^{* *} \\
(0.468)\end{array}$ \\
\hline Unemployment rate $\times$ lowest wage quartile & & $\begin{array}{c}3.600^{* * *} \\
(0.748)\end{array}$ & \\
\hline Unemployment rate $\times$ second wage quartile & & ref. & \\
\hline Unemployment rate $\times$ third wage quartile & & $\begin{array}{l}-0.450 \\
(0.366)\end{array}$ & \\
\hline Unemployment rate $\times$ highest wage quartile & & $\begin{array}{l}-0.673 \\
(0.461)\end{array}$ & \\
\hline Unemployment rate $\times$ less than $\mathrm{HS}$ & & $\begin{array}{l}2.568^{*} \\
(1.135)\end{array}$ & \\
\hline Unemployment rate $\times$ HS, no BA & & ref. & \\
\hline Unemployment rate $\times \mathrm{BA}$ or higher & & $\begin{array}{l}-0.308 \\
(0.336)\end{array}$ & \\
\hline Covered by a union & $\begin{array}{l}5.119^{* *} \\
(1.651)\end{array}$ & $\begin{array}{l}4.948^{* *} \\
(1.635)\end{array}$ & $\begin{array}{l}3.570^{*} \\
(1.739)\end{array}$ \\
\hline Covered by a union $\times$ lowest wage quartile & & & $\begin{array}{c}-9.697^{* *} \\
(3.466)\end{array}$ \\
\hline Covered by a union $\times$ second wage quartile & & & ref. \\
\hline Covered by a union $\times$ third wage quartile & & & $\begin{array}{c}2.229 \\
(2.808)\end{array}$ \\
\hline Covered by a union $\times$ highest wage quartile & & & $\begin{array}{c}2.929 \\
(2.732)\end{array}$ \\
\hline Covered by a union $\times$ less than HS & & & $\begin{array}{l}0.0715 \\
(4.726)\end{array}$ \\
\hline Covered by a union $\times$ HS, no BA & & & ref. \\
\hline Covered by a union $\times$ BA or higher & & & $\begin{array}{c}1.095 \\
(2.446)\end{array}$ \\
\hline Demographic Controls & Yes & Yes & Yes \\
\hline Job Controls & Yes & Yes & Yes \\
\hline State FE & Yes & Yes & Yes \\
\hline Year and Month FE & Yes & Yes & Yes \\
\hline Observations & 431436 & 431436 & 431436 \\
\hline
\end{tabular}


Figure 1: State-Level Unemployment Rates and Union Coverage, by Year (1995-2017)

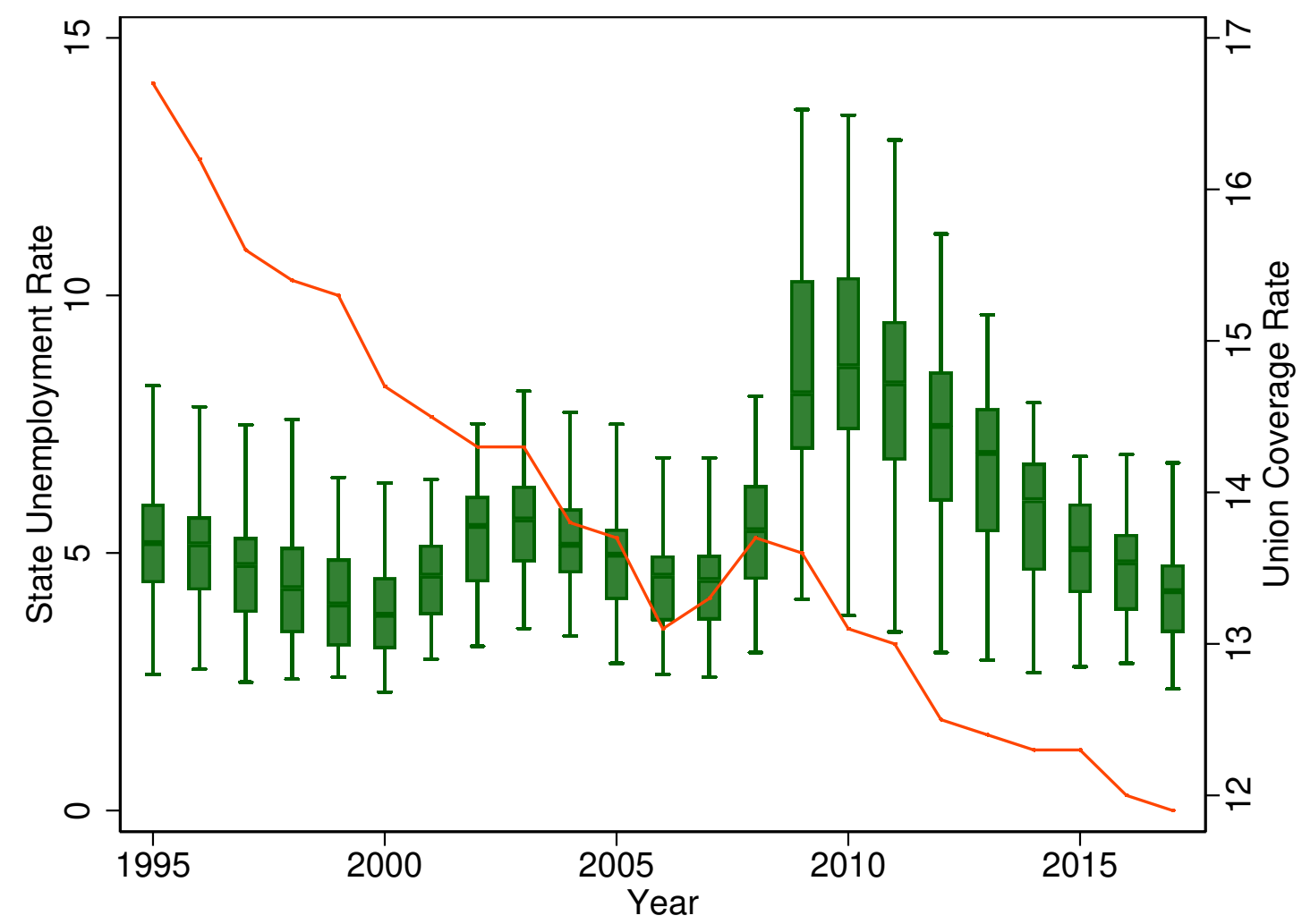

Note: The green box plots show within-year variation in state-level unemployment rates, measured on the left axis; the orange line shows the national percentage of individuals who are covered by unions at their work, measured on the right axis. Box plots exclude outside values. 
Figure 2: Trends in the CV of Weekly Hours Worked, by Wage Quartile (1995-2016)

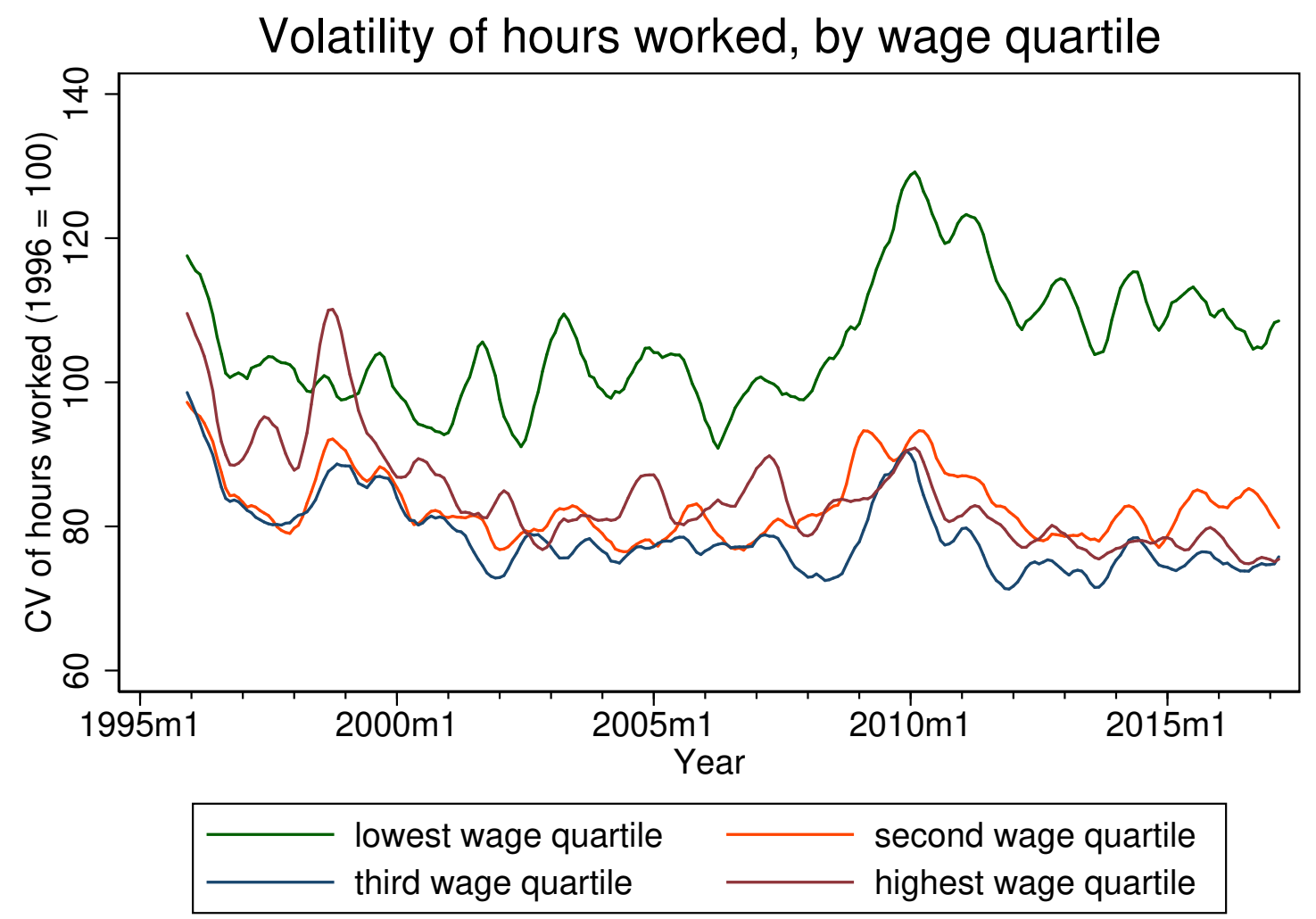

Note: Time series are seasonally adjusted and smoothed using an Epanechnikov kernel with bandwidth equal to six months. See Appendix C for more details. 
Figure 3: Trends in the CV of Weekly Hours Worked, by Education (1995-2016)

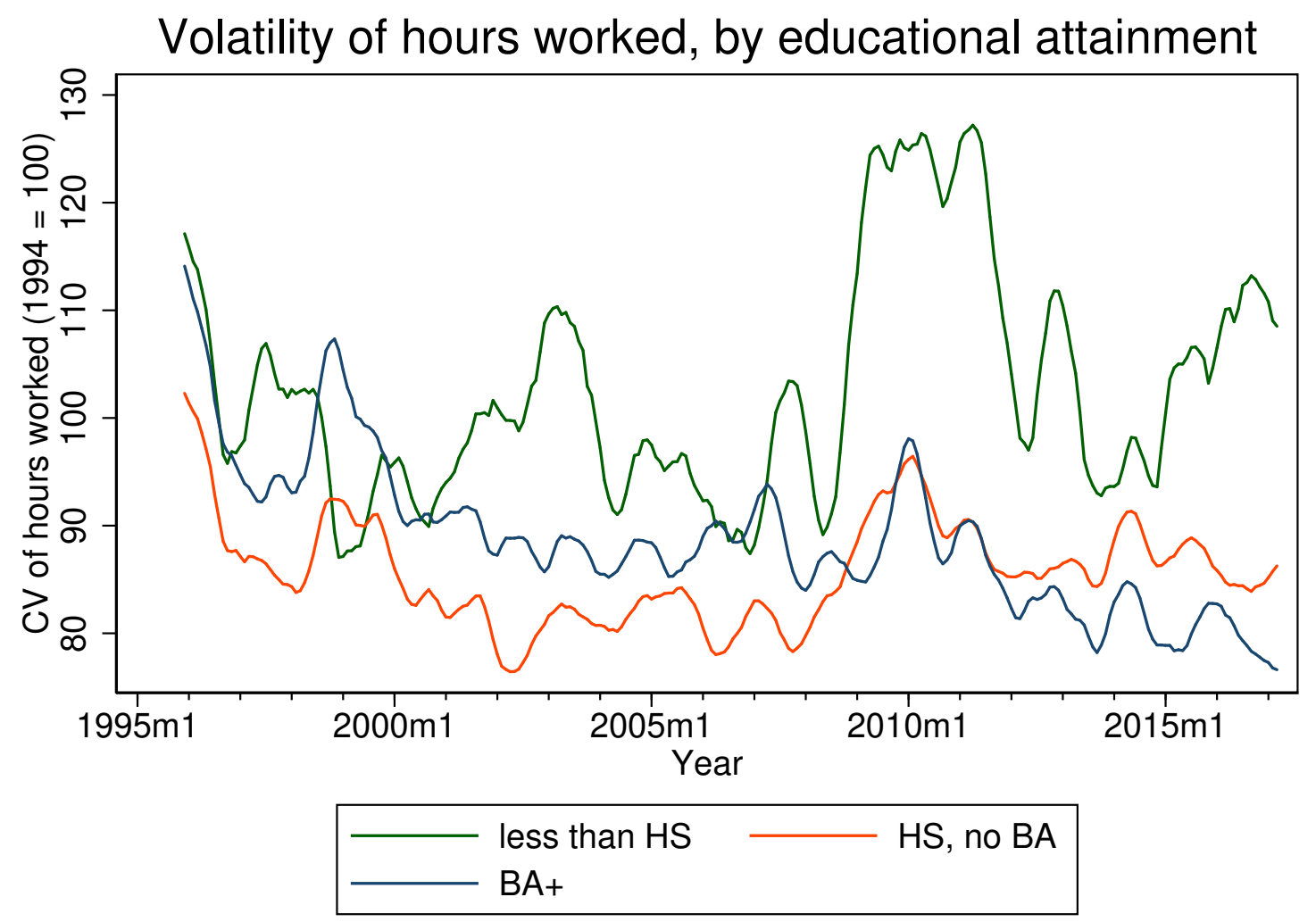

Note: Time series are seasonally adjusted and smoothed using an Epanechnikov kernel with bandwidth equal to six months. See Appendix C for more details. 
Figure 4: Predicted Class Gaps in Work Hour Volatility by State-Level Unemployment Rate

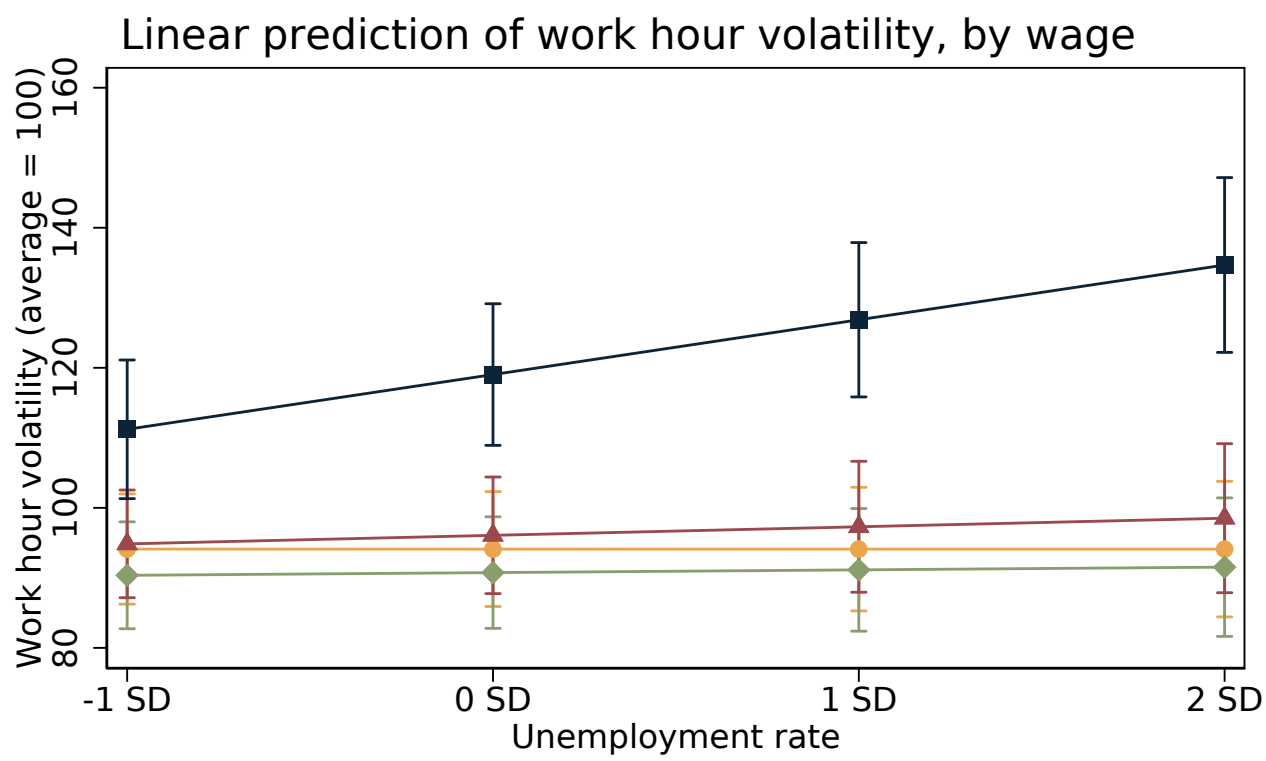
Top quartile
Second quartile
Third quartile
Lowest quartile

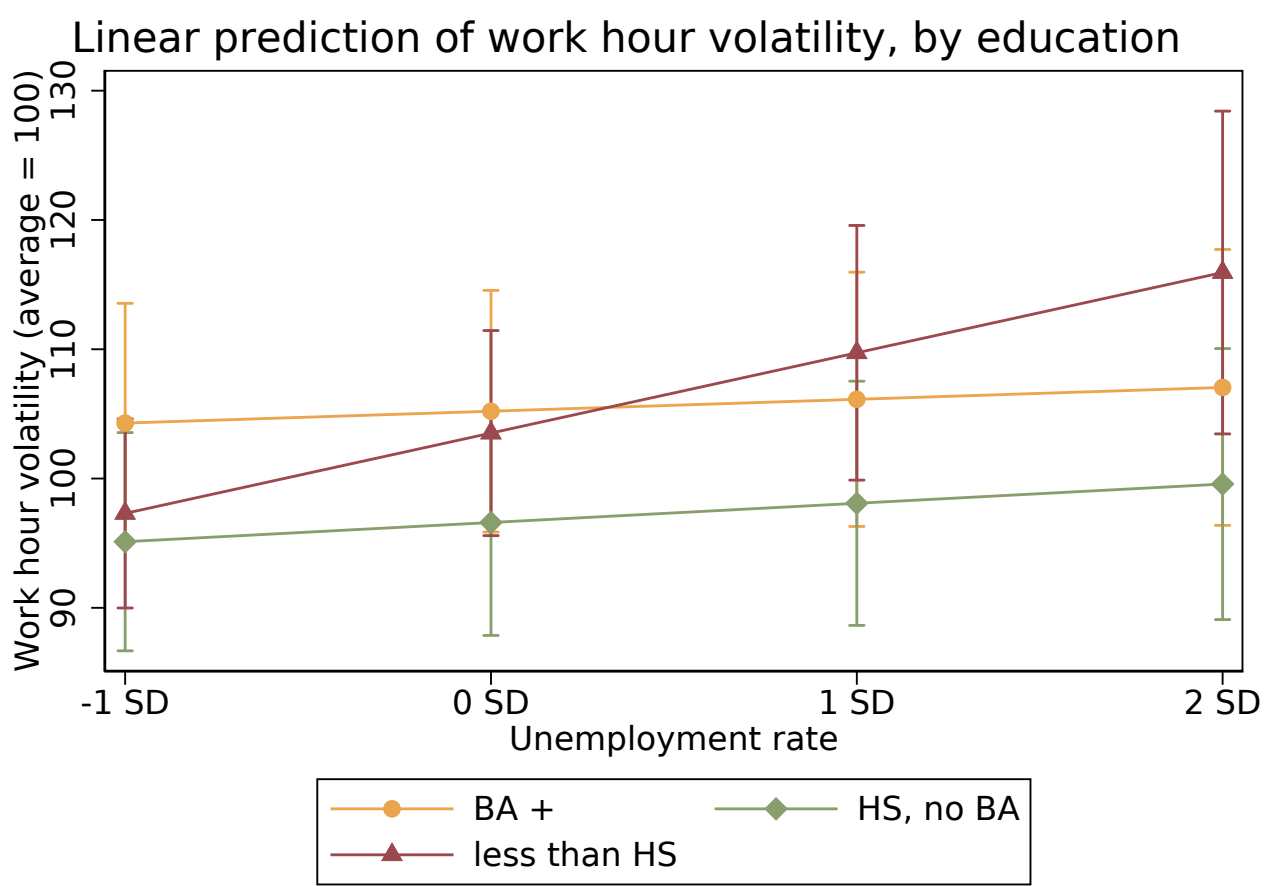


Figure 5: Predicted Class Gaps in Work Hour Volatility by Union Coverage

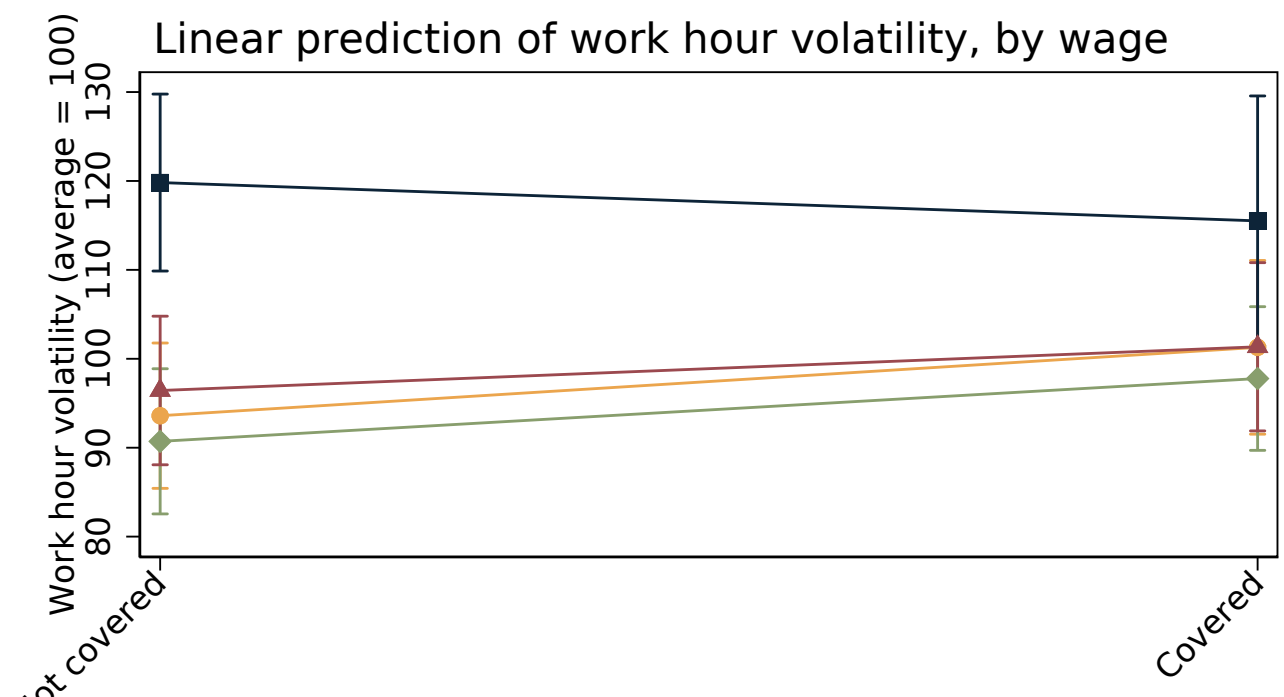

Covered by a union

\begin{tabular}{|c|c|}
\hline $\begin{array}{l}\longrightarrow \text { Top quartile } \\
\text { Second quartile }\end{array}$ & $\begin{array}{l}\longrightarrow \text { Third quartile } \\
\text { Lowest quartile }\end{array}$ \\
\hline
\end{tabular}

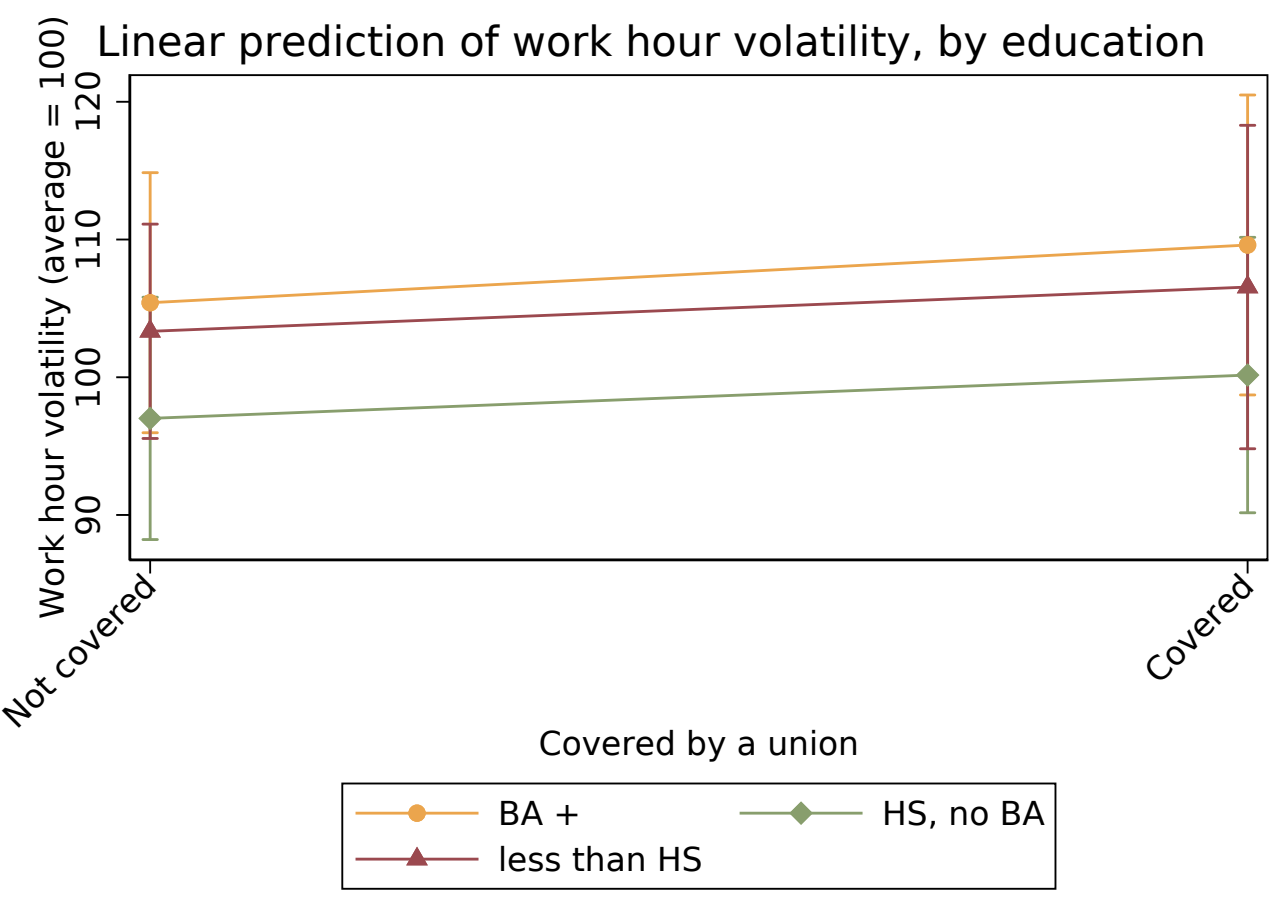




\section{Appendix Table 1: Predicting Class Polarization in the SD of Weekly Hours Worked}

\begin{tabular}{|c|c|c|c|}
\hline & $(1)$ & $(2)$ & $(3)$ \\
\hline Lowest wage quartile & $\begin{array}{c}13.05^{* * *} \\
(1.355)\end{array}$ & $\begin{array}{c}13.14^{* * *} \\
(1.363)\end{array}$ & $\begin{array}{c}12.71^{* * *} \\
(1.423)\end{array}$ \\
\hline Second wage quartile & ref. & ref. & ref. \\
\hline Third wage quartile & $\begin{array}{l}-1.946^{*} \\
(0.852)\end{array}$ & $\begin{array}{l}-1.928^{*} \\
(0.853)\end{array}$ & $\begin{array}{l}-2.048^{*} \\
(0.849)\end{array}$ \\
\hline Highest wage quartile & $\begin{array}{l}0.0186 \\
(1.364)\end{array}$ & $\begin{array}{l}0.0941 \\
(1.351)\end{array}$ & $\begin{array}{r}-0.0316 \\
(1.360)\end{array}$ \\
\hline Less than HS & $\begin{array}{c}0.405 \\
(1.731)\end{array}$ & $\begin{array}{c}0.775 \\
(1.695)\end{array}$ & $\begin{array}{c}0.234 \\
(1.704)\end{array}$ \\
\hline HS, no BA & ref. & ref. & ref. \\
\hline BA or higher & $\begin{array}{c}10.90^{* * *} \\
(0.923)\end{array}$ & $\begin{array}{c}11.00^{* * *} \\
(0.930)\end{array}$ & $\begin{array}{c}10.88^{* * *} \\
(0.931)\end{array}$ \\
\hline Unemployment rate & $\begin{array}{c}0.304 \\
(0.379)\end{array}$ & $\begin{array}{c}0.327 \\
(0.377)\end{array}$ & $\begin{array}{l}0.308 \\
(0.380)\end{array}$ \\
\hline Unemployment rate $\times$ less than HS & & $\begin{array}{l}2.053^{*} \\
(0.792)\end{array}$ & \\
\hline Unemployment rate $\times$ HS, no $\mathrm{BA}$ & & ref. & \\
\hline Unemployment rate $\times$ BA or higher & & $\begin{array}{l}-0.508 \\
(0.340)\end{array}$ & \\
\hline Unemployment rate $\times$ lowest wage quartile & & $\begin{array}{l}1.701^{* *} \\
(0.615)\end{array}$ & \\
\hline Unemployment rate $\times$ second wage quartile & & ref. & \\
\hline Unemployment rate $\times$ third wage quartile & & $\begin{array}{l}0.0915 \\
(0.430)\end{array}$ & \\
\hline Unemployment rate $\times$ highest wage quartile & & $\begin{array}{c}0.495 \\
(0.443)\end{array}$ & \\
\hline Covered by a union & $\begin{array}{c}8.184^{* * *} \\
(1.638)\end{array}$ & $\begin{array}{c}8.109^{* * *} \\
(1.628)\end{array}$ & $\begin{array}{c}7.304^{* * *} \\
(1.720)\end{array}$ \\
\hline Covered by a union $\times$ lowest wage quartile & & & $\begin{array}{c}-6.333^{+} \\
(3.677)\end{array}$ \\
\hline Covered by a union $\times$ second wage quartile & & & ref. \\
\hline Covered by a union $\times$ third wage quartile & & & $\begin{array}{l}0.555 \\
(2.212)\end{array}$ \\
\hline Covered by a union $\times$ highest wage quartile & & & $\begin{array}{l}-1.037 \\
(2.486)\end{array}$ \\
\hline Covered by a union $\times$ less than HS & & & $\begin{array}{l}-3.473 \\
(3.949)\end{array}$ \\
\hline Covered by a union $\times$ HS, no BA & & & ref. \\
\hline Covered by a union $\times$ BA or higher & & & $\begin{array}{l}1.540 \\
(2.581)\end{array}$ \\
\hline Demographic Controls & Yes & Yes & Yes \\
\hline Job Controls & Yes & Yes & Yes \\
\hline State FE & Yes & Yes & Yes \\
\hline Year and Month FE & Yes & Yes & Yes \\
\hline Observations & 431436 & 431436 & 431436 \\
\hline
\end{tabular}


Appendix Table 2: Comparing the CV of Weekly Hours Worked to Other Measures of Work Hour Volatility

\begin{tabular}{lcc}
\hline & $(1)$ & $(2)$ \\
\hline Irregular shift set by employer & 14.63 & \\
& $(10.45)$ & \\
Report that usual weekly work hours "vary" & & $80.75^{* * *}$ \\
& Yes & Yes \\
Year FE & 2289 & 431436 \\
\hline Observations & & \\
\hline Standard errors in parentheses & \\
$+p<.1,{ }^{*} p<.05,{ }^{* *} p<.01,{ }^{* * *} p<.001$ &
\end{tabular}


Appendix Table 3: Distribution of the CV of Weekly Hours Worked, by Control Over Start/End Time of Work

\begin{tabular}{|c|c|c|}
\hline $\mathrm{CV}$ & Control over Start/End & No Control over Start/End \\
\hline Mean & .093 & .078 \\
\hline$\overline{2} 5 \overline{t h}$ percentile - & .011 & 0 \\
\hline 50th percentile & .065 & .051 \\
\hline 75th percentile & .131 & .111 \\
\hline 90th percentile & .220 & .201 \\
\hline 95th percentile & .295 & .276 \\
\hline
\end{tabular}




\section{Appendix Table 4: Regression Results from Models Predicting the CV of Weekly Hours Worked, Full Model Results}

\begin{tabular}{|c|c|c|c|}
\hline & $(1)$ & $(2)$ & $(3)$ \\
\hline Lowest wage quartile & $\begin{array}{l}23.11^{* * *} \\
(1.688)\end{array}$ & $\begin{array}{l}23.27^{* * *} \\
(1.707)\end{array}$ & $\begin{array}{l}22.58^{* * *} \\
(1.754)\end{array}$ \\
\hline Second wage quartile & ref. & ref. & ref. \\
\hline Third wage quartile & $\begin{array}{l}-5.354^{* * *} \\
(0.832)\end{array}$ & $\begin{array}{l}-5.336^{* * *} \\
(0.840)\end{array}$ & $\begin{array}{l}-5.473^{* * *} \\
(0.817)\end{array}$ \\
\hline Highest wage quartile & $\begin{array}{l}-2.284^{+} \\
(1.301)\end{array}$ & $\begin{array}{l}-2.005 \\
(1.286)\end{array}$ & $\begin{array}{l}-2.550^{+} \\
(1.316)\end{array}$ \\
\hline Less than HS & $\begin{array}{l}6.449^{* * *} \\
(1.783)\end{array}$ & $\begin{array}{l}6.985^{* * *} \\
(1.775)\end{array}$ & $\begin{array}{l}6.395^{* * *} \\
(1.806)\end{array}$ \\
\hline $\mathrm{HS}$, no BA & ref. & ref. & ref. \\
\hline BA or higher & $\begin{array}{l}8.578^{* * *} \\
(0.830)\end{array}$ & $\begin{array}{l}8.696^{* * *} \\
(0.850)\end{array}$ & $\begin{array}{l}8.613^{* * *} \\
(0.843)\end{array}$ \\
\hline Unemployment rate & $\begin{array}{l}1.342^{* *} \\
(0.468)\end{array}$ & $\begin{array}{l}1.400^{* *} \\
(0.463)\end{array}$ & $\begin{array}{l}1.348^{* *} \\
(0.468)\end{array}$ \\
\hline Unemployment rate $\times$ Lowest wage quartile & & $\begin{array}{l}3.600^{* * *} \\
(0.748)\end{array}$ & \\
\hline Unemployment rate $\times$ second wage quartile & & ref. & \\
\hline Unemployment rate $\times$ Third wage quartile & & $\begin{array}{l}-0.450 \\
(0.366)\end{array}$ & \\
\hline Unemployment rate $\times$ Highest wage quartile & & $\begin{array}{l}-0.673 \\
(0.461)\end{array}$ & \\
\hline Unemployment rate $\times$ Less than HS & & $\begin{array}{l}2.568^{*} \\
(1.135)\end{array}$ & \\
\hline Unemployment rate $\times$ HS, no $\mathrm{BA}$ & & ref. & \\
\hline Unemployment rate $\times \mathrm{BA}$ or higher & & $\begin{array}{l}-0.308 \\
(0.336)\end{array}$ & \\
\hline Covered by a union & $\begin{array}{l}5.119^{* *} \\
(1.651)\end{array}$ & $\begin{array}{l}4.948^{* *} \\
(1.635)\end{array}$ & $\begin{array}{l}3.570^{*} \\
(1.739)\end{array}$ \\
\hline Covered by a union $\times$ lowest wage quartile & & & $\begin{array}{l}-9.697^{* *} \\
(3.466)\end{array}$ \\
\hline Covered by a union $\times$ second wage quartile & & & ref. \\
\hline Covered by a union $\times$ third wage quartile & & & $\begin{array}{l}2.229 \\
(2.808)\end{array}$ \\
\hline Covered by a union $\times$ highest wage quartile & & & $\begin{array}{l}2.929 \\
(2.732)\end{array}$ \\
\hline Covered by a union $\times$ less than HS & & & $\begin{array}{l}0.0715 \\
(4.726)\end{array}$ \\
\hline Covered by a union $\times$ HS, no BA & & & ref. \\
\hline Covered by a union $\times$ BA or higher & & & $\begin{array}{l}1.095 \\
(2.446)\end{array}$ \\
\hline Female (ref.: male) & $\begin{array}{l}-4.792^{* * *} \\
(1.132)\end{array}$ & $\begin{array}{l}-4.796^{* * *} \\
(1.141)\end{array}$ & $\begin{array}{l}-4.816^{* * *} \\
(1.133)\end{array}$ \\
\hline Black (ref.: White) & $\begin{array}{l}-0.388 \\
(1.654)\end{array}$ & $\begin{array}{l}-0.364 \\
(1.657)\end{array}$ & $\begin{array}{l}-0.310 \\
(1.657)\end{array}$ \\
\hline Other race (ref.: White) & $\begin{array}{l}-4.096^{*} \\
(1.792)\end{array}$ & $\begin{array}{l}-4.120^{*} \\
(1.804)\end{array}$ & $\begin{array}{l}-4.094^{*} \\
(1.801)\end{array}$ \\
\hline Age $<30$ (ref.: age $40-49$ ) & $\begin{array}{l}-0.0647 \\
(1.014)\end{array}$ & $\begin{array}{l}-0.0663 \\
(1.007)\end{array}$ & $\begin{array}{l}-0.110 \\
(1.012)\end{array}$ \\
\hline Age 30-39 (ref.: age 40-49) & $\begin{array}{l}-1.262 \\
(0.783)\end{array}$ & $\begin{array}{c}-1.307^{+} \\
(0.771)\end{array}$ & $\begin{array}{l}-1.270 \\
(0.786)\end{array}$ \\
\hline Age $50+$ (ref.: age $40-49)$ & $\begin{array}{l}7.906^{* * *} \\
(1.016)\end{array}$ & $\begin{array}{l}8.054^{* * *} \\
(1.030)\end{array}$ & $\begin{array}{l}7.872^{* * *} \\
(1.015)\end{array}$ \\
\hline Unmarried (ref.: married) & $\begin{array}{l}7.613^{\text {*** }} \\
(0.672)\end{array}$ & $\begin{array}{l}7.448^{* * *} \\
(0.683)\end{array}$ & $\begin{array}{l}7.596^{* * *} \\
(0.676)\end{array}$ \\
\hline
\end{tabular}




\begin{tabular}{|c|c|c|c|}
\hline & $(1)$ & $(2)$ & $(3)$ \\
\hline Has one HH child (ref.: has no HH children) & $\begin{array}{l}-4.809^{* * *} \\
(1.033)\end{array}$ & $\begin{array}{l}-4.755^{* * *} \\
(1.012)\end{array}$ & $\begin{array}{l}-4.816^{* * *} \\
(1.032)\end{array}$ \\
\hline Has two HH children (ref.: has no HH children) & $\begin{array}{l}-3.571^{* * *} \\
(0.787)\end{array}$ & $\begin{array}{l}-3.530^{* * *} \\
(0.800)\end{array}$ & $\begin{array}{l}-3.599^{* * *} \\
(0.779)\end{array}$ \\
\hline Has three HH children (ref.: has no HH children) & $\begin{array}{l}0.696 \\
(2.035)\end{array}$ & $\begin{array}{l}0.671 \\
(2.029)\end{array}$ & $\begin{array}{l}0.651 \\
(2.038)\end{array}$ \\
\hline Foreign-born (ref.: native-born) & $\begin{array}{l}-9.016^{* * *} \\
(1.277)\end{array}$ & $\begin{array}{l}-9.203^{* * *} \\
(1.246)\end{array}$ & $\begin{array}{l}-9.026^{* * *} \\
(1.283)\end{array}$ \\
\hline Occ.: management (ref.: production) & $\begin{array}{l}-3.098^{*} \\
(1.485)\end{array}$ & $\begin{array}{l}-3.214^{*} \\
(1.487)\end{array}$ & $\begin{array}{l}-2.807^{+} \\
(1.504)\end{array}$ \\
\hline Occ.: business operations specialists (ref.: production) & $\begin{array}{l}-12.39^{* * *} \\
(2.125)\end{array}$ & $\begin{array}{l}-12.50^{* * *} \\
(2.127)\end{array}$ & $\begin{array}{l}-12.13^{* * *} \\
(2.117)\end{array}$ \\
\hline Occ.: financial specialists (ref.: production) & $\begin{array}{l}-13.23^{* * *} \\
(1.738)\end{array}$ & $\begin{array}{l}-13.46^{* * *} \\
(1.739)\end{array}$ & $\begin{array}{l}-12.89^{* * *} \\
(1.776)\end{array}$ \\
\hline Occ.: computer and mathematical (ref.: production) & $\begin{array}{l}-22.48^{* * *} \\
(2.146)\end{array}$ & $\begin{array}{l}-22.50^{* * *} \\
(2.143)\end{array}$ & $\begin{array}{l}-22.07^{* * *} \\
(2.148)\end{array}$ \\
\hline Occ.: architecture and engineering (ref.: production) & $\begin{array}{l}-18.24^{* * *} \\
(2.039)\end{array}$ & $\begin{array}{l}-18.40^{* * *} \\
(2.025)\end{array}$ & $\begin{array}{l}-17.86^{* * *} \\
(2.036)\end{array}$ \\
\hline Occ.: technicians (ref.: production) & $\begin{array}{l}1.047 \\
(4.205)\end{array}$ & $\begin{array}{l}0.902 \\
(4.199)\end{array}$ & $\begin{array}{l}1.158 \\
(4.234)\end{array}$ \\
\hline Occ.: life, physical, and social science (ref.: production) & $\begin{array}{l}-9.962^{* * *} \\
(2.712)\end{array}$ & $\begin{array}{l}-10.25^{* * *} \\
(2.718)\end{array}$ & $\begin{array}{l}-9.738^{* * *} \\
(2.696)\end{array}$ \\
\hline Occ.: community and social workers (ref.: production) & $\begin{array}{l}-4.927^{+} \\
(2.797)\end{array}$ & $\begin{array}{l}-4.903^{+} \\
(2.790)\end{array}$ & $\begin{array}{l}-4.960^{+} \\
(2.782)\end{array}$ \\
\hline Occ.: legal (ref.: production) & $\begin{array}{l}-5.293^{+} \\
(2.942)\end{array}$ & $\begin{array}{l}-5.349^{+} \\
(2.931)\end{array}$ & $\begin{array}{c}-4.974^{+} \\
(2.931)\end{array}$ \\
\hline Occ.: education, training, and library (ref.: production) & $\begin{array}{l}15.67^{* * *} \\
(2.884)\end{array}$ & $\begin{array}{l}15.64^{* * *} \\
(2.868)\end{array}$ & $\begin{array}{l}15.28^{* * *} \\
(2.826)\end{array}$ \\
\hline Occ.: arts, design, entertainment, sports, and media (ref.: production) & $\begin{array}{l}11.91^{\text {*** }} \\
(2.566)\end{array}$ & $\begin{array}{l}11.80^{\text {*** }} \\
(2.603)\end{array}$ & $\begin{array}{l}12.11^{\text {*** }} \\
(2.566)\end{array}$ \\
\hline Occ.: healthcare practitioners and technical (ref.: production) & $\begin{array}{l}0.633 \\
(1.897)\end{array}$ & $\begin{array}{l}0.533 \\
(1.901)\end{array}$ & $\begin{array}{l}0.762 \\
(1.867)\end{array}$ \\
\hline Occ.: healthcare support (ref.: production) & $\begin{array}{l}6.240^{*} \\
(2.645)\end{array}$ & $\begin{array}{l}6.197^{*} \\
(2.634)\end{array}$ & $\begin{array}{l}6.407^{*} \\
(2.648)\end{array}$ \\
\hline Occ.: protective service (ref.: production) & $\begin{array}{l}14.90^{* * *} \\
(2.718)\end{array}$ & $\begin{array}{l}14.77^{* * *} \\
(2.720)\end{array}$ & $\begin{array}{l}14.87^{* * *} \\
(2.729)\end{array}$ \\
\hline Occ.: food preparation and service (ref.: production) & $\begin{array}{l}16.35^{\text {*** }} \\
(2.759)\end{array}$ & $\begin{array}{l}16.16^{\text {*** }} \\
(2.767)\end{array}$ & $\begin{array}{l}16.31^{\text {*** }} \\
(2.785)\end{array}$ \\
\hline Occ.: building and grounds cleaning and maintenance (ref.: production) & $\begin{array}{l}-2.133 \\
(2.635)\end{array}$ & $\begin{array}{l}-2.293 \\
(2.621)\end{array}$ & $\begin{array}{l}-2.122 \\
(2.646)\end{array}$ \\
\hline Occ.: personal care and service (ref.: production) & $\begin{array}{l}11.53^{* *} \\
(4.114)\end{array}$ & $\begin{array}{l}10.86^{* *} \\
(4.050)\end{array}$ & $\begin{array}{l}11.58^{* *} \\
(4.215)\end{array}$ \\
\hline Occ.: sales and related (ref.: production) & $\begin{array}{l}0.590 \\
(1.917)\end{array}$ & $\begin{array}{l}0.471 \\
(1.919)\end{array}$ & $\begin{array}{l}0.721 \\
(1.916)\end{array}$ \\
\hline Occ.: office and administrative support (ref.: production) & $\begin{array}{l}-21.64^{* * *} \\
(1.577)\end{array}$ & $\begin{array}{l}-21.82^{* * *} \\
(1.564)\end{array}$ & $\begin{array}{l}-21.57^{* * *} \\
(1.573)\end{array}$ \\
\hline Occ.: farming, fishing, and forestry (ref.: production) & $\begin{array}{l}8.406 \\
(8.990)\end{array}$ & $\begin{array}{l}8.533 \\
(9.188)\end{array}$ & $\begin{array}{l}8.352 \\
(8.984)\end{array}$ \\
\hline Occ.: construction (ref.: production) & $\begin{array}{l}21.27^{* * *} \\
(2.678)\end{array}$ & $\begin{array}{l}21.08^{* * *} \\
(2.645)\end{array}$ & $\begin{array}{l}21.16^{* * *} \\
(2.689)\end{array}$ \\
\hline Occ.: extraction (ref.: production) & $\begin{array}{l}51.06^{* * *} \\
(14.36)\end{array}$ & $\begin{array}{l}51.08^{* * *} \\
(14.41)\end{array}$ & $\begin{array}{l}51.09^{* * *} \\
(14.37)\end{array}$ \\
\hline Occ.: installation, maintenance, and repair (ref.: production) & $\begin{array}{l}-6.632^{* * *} \\
(1.640)\end{array}$ & $\begin{array}{l}-6.684^{* * *} \\
(1.612)\end{array}$ & $\begin{array}{l}-6.589^{* * *} \\
(1.635)\end{array}$ \\
\hline Occ.: transportation and material moving (ref.: production) & $\begin{array}{l}14.44^{* * *} \\
(1.493)\end{array}$ & $\begin{array}{l}14.37^{* * *} \\
(1.486)\end{array}$ & $\begin{array}{l}14.51^{* * *} \\
(1.516)\end{array}$ \\
\hline
\end{tabular}


Continued from previous page

\begin{tabular}{|c|c|c|c|}
\hline & $(1)$ & $(2)$ & $(3)$ \\
\hline Ind.: agriculture (ref.: transportation) & $\begin{array}{l}41.26^{* * *} \\
(8.228)\end{array}$ & $\begin{array}{l}41.04^{* * *} \\
(8.316)\end{array}$ & $\begin{array}{l}41.28^{* * *} \\
(8.246)\end{array}$ \\
\hline Ind.: mining (ref.: transportation) & $\begin{array}{l}20.13^{* * *} \\
(4.560)\end{array}$ & $\begin{array}{l}20.46^{* * *} \\
(4.607)\end{array}$ & $\begin{array}{l}20.33^{* * *} \\
(4.550)\end{array}$ \\
\hline Ind.: construction (ref.: transportation) & $\begin{array}{l}14.86^{* * *} \\
(2.234)\end{array}$ & $\begin{array}{l}15.01^{* * *} \\
(2.251)\end{array}$ & $\begin{array}{l}15.04^{* * *} \\
(2.201)\end{array}$ \\
\hline Ind.: manufacturing (ref.: transportation) & $\begin{array}{l}-5.614^{* * *} \\
(1.385)\end{array}$ & $\begin{array}{l}-5.524^{* * *} \\
(1.400)\end{array}$ & $\begin{array}{l}-5.422^{* * *} \\
(1.362)\end{array}$ \\
\hline Ind.: wholesale trade (ref.: transportation) & $\begin{array}{l}-13.82^{* * *} \\
(1.574)\end{array}$ & $\begin{array}{l}-13.87^{* * *} \\
(1.556)\end{array}$ & $\begin{array}{l}-13.66^{* * *} \\
(1.539)\end{array}$ \\
\hline Ind.: retail trade (ref.: transportation) & $\begin{array}{l}-4.508^{* * *} \\
(1.275)\end{array}$ & $\begin{array}{l}-4.543^{* * *} \\
(1.258)\end{array}$ & $\begin{array}{l}-4.494^{* *} \\
(1.291)\end{array}$ \\
\hline Ind.: finance, insurance, and real estate (ref.: transportation) & $\begin{array}{l}-14.62^{* * *} \\
(1.371)\end{array}$ & $\begin{array}{l}-14.53^{* * *} \\
(1.375)\end{array}$ & $\begin{array}{l}-14.41^{* * *} \\
(1.374)\end{array}$ \\
\hline Ind.: business and repair services (ref.: transportation) & $\begin{array}{l}-2.203 \\
(1.780)\end{array}$ & $\begin{array}{l}-2.200 \\
(1.763)\end{array}$ & $\begin{array}{l}-2.051 \\
(1.798)\end{array}$ \\
\hline Ind.: personal services (ref.: transportation) & $\begin{array}{l}12.40^{* * *} \\
(2.475)\end{array}$ & $\begin{array}{l}12.77^{* * *} \\
(2.509)\end{array}$ & $\begin{array}{l}12.50^{* * *} \\
(2.398)\end{array}$ \\
\hline Ind.: entertainment and recreation services (ref.: transportation) & $\begin{array}{l}11.32^{* *} \\
(4.047)\end{array}$ & $\begin{array}{l}11.56^{* *} \\
(4.072)\end{array}$ & $\begin{array}{l}11.46^{* *} \\
(4.061)\end{array}$ \\
\hline Ind.: professional services (ref.: transportation) & $\begin{array}{l}-2.789^{+} \\
(1.572)\end{array}$ & $\begin{array}{l}-2.711^{+} \\
(1.587)\end{array}$ & $\begin{array}{l}-2.596 \\
(1.560)\end{array}$ \\
\hline Ind.: public administration (ref.: transportation) & $\begin{array}{l}-13.83^{* * *} \\
(2.598)\end{array}$ & $\begin{array}{l}-13.67^{* * *} \\
(2.602)\end{array}$ & $\begin{array}{l}-13.82^{* * *} \\
(2.589)\end{array}$ \\
\hline State FE & Yes & Yes & Yes \\
\hline Year and Month FE & Yes & Yes & Yes \\
\hline Observations & 431436 & 431436 & 431436 \\
\hline
\end{tabular}

Standard errors in parentheses

${ }^{+} p<.1,{ }^{*} p<.05,{ }^{* *} p<.01,{ }^{* * *} p<.001$ 


\section{Appendix Table 5: Alternative Models Predicting The Relationship Between Associa- tional Worker Power and Polarization in Work Hour Volatility}

\begin{tabular}{|c|c|c|c|c|}
\hline & $(1)$ & $(2)$ & $(3)$ & $(4)$ \\
\hline Lowest wage quartile & $\begin{array}{c}22.50^{* * *} \\
(1.672)\end{array}$ & $\begin{array}{c}21.91^{* * *} \\
(1.730)\end{array}$ & $\begin{array}{c}22.39^{* * *} \\
(1.673)\end{array}$ & $\begin{array}{c}21.43^{* * *} \\
(1.735)\end{array}$ \\
\hline Second wage quartile & ref. & ref. & ref. & ref. \\
\hline Third wage quartile & $\begin{array}{c}-5.329^{* * *} \\
(0.798)\end{array}$ & $\begin{array}{c}-5.490^{* * *} \\
(0.792)\end{array}$ & $\begin{array}{c}-5.144^{* * *} \\
(0.806)\end{array}$ & $\begin{array}{c}-5.429^{* * *} \\
(0.781)\end{array}$ \\
\hline Highest wage quartile & $\begin{array}{c}-2.389^{+} \\
(1.264)\end{array}$ & $\begin{array}{l}-2.663^{*} \\
(1.285)\end{array}$ & $\begin{array}{c}-2.196^{+} \\
(1.307)\end{array}$ & $\begin{array}{c}-2.151^{+} \\
(1.280)\end{array}$ \\
\hline Less than HS & $\begin{array}{l}5.852^{* *} \\
(1.694)\end{array}$ & $\begin{array}{l}5.782^{* *} \\
(1.712)\end{array}$ & $\begin{array}{l}5.836^{* *} \\
(1.701)\end{array}$ & $\begin{array}{c}6.468^{* * *} \\
(1.703)\end{array}$ \\
\hline HS, no BA & ref. & ref. & ref. & ref. \\
\hline BA or higher & $\begin{array}{c}7.098^{* * *} \\
(0.758)\end{array}$ & $\begin{array}{c}7.149^{* * *} \\
(0.765)\end{array}$ & $\begin{array}{c}7.098^{* * *} \\
(0.762)\end{array}$ & $\begin{array}{c}7.044^{* * *} \\
(0.778)\end{array}$ \\
\hline Unemployment rate & $\begin{array}{l}1.165^{* *} \\
(0.408)\end{array}$ & $\begin{array}{l}1.171^{* *} \\
(0.408)\end{array}$ & $\begin{array}{l}1.189^{* *} \\
(0.409)\end{array}$ & $\begin{array}{l}1.199^{* *} \\
(0.408)\end{array}$ \\
\hline Member of a union & $\begin{array}{l}4.350^{* *} \\
(1.465)\end{array}$ & $\begin{array}{l}2.804^{+} \\
(1.539)\end{array}$ & & \\
\hline$\%$ region-ind. union coverage & & & $\begin{array}{l}0.360^{* * *} \\
(0.0876)\end{array}$ & $\begin{array}{c}0.357^{* * *} \\
(0.0938)\end{array}$ \\
\hline Member of a union $\times$ lowest wage quartile & & $\begin{array}{c}-10.42^{* *} \\
(3.613)\end{array}$ & & \\
\hline Member of a union $\times$ second wage quartile & & ref. & & \\
\hline Member of a union $\times$ third wage quartile & & $\begin{array}{c}3.857 \\
(2.539)\end{array}$ & & \\
\hline Member of a union $\times$ highest wage quartile & & $\begin{array}{c}3.352 \\
(2.558)\end{array}$ & & \\
\hline Member of a union $\times$ less than HS & & $\begin{array}{l}-1.591 \\
(4.109)\end{array}$ & & \\
\hline Member of a union $\times$ HS, no BA & & ref. & & \\
\hline Member of a union $\times$ BA or higher & & $\begin{array}{l}-2.315 \\
(2.094)\end{array}$ & & \\
\hline$\%$ region-ind. union coverage $\times$ lowest wage quartile & & & & $\begin{array}{c}-0.633^{* * *} \\
(0.144)\end{array}$ \\
\hline$\%$ region-ind. union coverage $\times$ second wage quartile & & & & ref. \\
\hline$\%$ region-ind. union coverage $\times$ third wage quartile & & & & $\begin{array}{c}-0.0939 \\
(0.0612)\end{array}$ \\
\hline$\%$ region-ind. union coverage $\times$ highest wage quartile & & & & $\begin{array}{c}-0.298^{* * *} \\
(0.0675)\end{array}$ \\
\hline$\%$ region-ind. union coverage $\times$ less than HS & & & & $\begin{array}{c}0.324 \\
(0.241)\end{array}$ \\
\hline$\%$ region-ind. union coverage $\times$ HS, no BA & & & & ref. \\
\hline$\%$ region-ind. union coverage $\times$ BA or higher & & & & $\begin{array}{l}-0.0235 \\
(0.0627)\end{array}$ \\
\hline Demographic Controls & Yes & Yes & Yes & Yes \\
\hline Job Controls & Yes & Yes & Yes & Yes \\
\hline State FE & Yes & Yes & Yes & Yes \\
\hline Year and Month FE & Yes & Yes & Yes & Yes \\
\hline Observations & 431436 & 431436 & 431436 & 431436 \\
\hline
\end{tabular}

Standard errors in parentheses

${ }^{+} p<.1,{ }^{*} p<.05,{ }^{* *} p<.01,{ }^{* * *} p<.001$ 


\section{Appendix A: Measurement of Occupation, Industry, and Regional- Level Industry Coverage}

In our regression models, we control for the occupation and industry of respondents' jobs. For occupations, we use the four-digit OCC2010 variable provided by IPUMS, and organize these more detailed occupational codes into 26 broader groups created by IPUMS. These groups are: management in business, science, and arts (10-430); business operations specialists (500-730); financial specialists (800-950); computer and mathematical (1000-1240); architecture and engineering (1300-1540); technicians (1550-1560); life, physical, and social science (1600-1980); community and social services (2000-2060); legal (2100-2150); education, training, and library (2200-2550); arts, design, entertainment, sports, and media (2600-2920); healthcare practitioners and technicians (30003540); healthcare support (3600-3650); protective service (3700-3950); food preparation and serving (4000-4150); building and grounds cleaning and maintenance (4200-4250); personal care and service (4300-4650); sales and related (4700-4965); office and administrative support (5000-5940); farming, fisheries, and forestry (6005-6130); construction (6200-6765); extraction (6800-6940); installation, maintenance, and repair (7000-7630); production (7700-8965); transportation and material moving (9000-9750); and military (9800-9830).

For industries, we use the three-digit IND1990 variable provided by IPUMS, and organize these more detailed industrial codes into 14 larger groups provided by IPUMS: These groups are: agriculture, forestry, and fisheries (10-32); mining (40-50); construction (60); manufacturing (100-392); transportation, communications, and other public utilities (400-472); wholesale trade (500-571); retail trade (580-691); finance, insurance, and real estate (700-712); business and repair services (721-760); personal services (761-791); entertainment and recreation services (800-810); professional and related services (812-893); public administration (900-932); and active duty military (940-960).

We create industry-specific regional union coverage using these industry codes, and the regional divisions collected by the CPS: New England Division, Middle Atlantic Division, East North Central Division, West North Central Division, South Atlantic Division, East South Central Division, West South Central Division, Mountain Division, and Pacific Division. We average industry-specific regional union coverage over the twelve Outgoing Rotation Groups (months 4 and 8 in the CPS survey rotation, in which respondents are asked about union coverage and membership) in a calendar year. Our method is thus similar to that of Western and Rosenfeld (2011), though we use slightly fewer industrial categories and more detailed regional categories.

\section{References}

Western, Bruce and Jake Rosenfeld. 2011. "Unions, Norms, and the Rise in US Wage Inequality." American Sociological Review. 76(4):513-537. 


\section{Appendix B: Creating Analysis Weights}

We base our analysis weights on the IPUMS-provided weight EARNWT, which is a person-level weight calculated for CPS respondents who fill out the earner study (those who are 15 or older, not in the armed forces, and who are in the fourth or eighth survey month in the CPS sample). We use EARNWT rather than the final basic weight (labeled WTFINL on the IPUMS website) because our analysis uses several variables from the earner study, including workers' hourly wages, weekly earnings, whether they are paid hourly or not, and/or whether they are covered by a union at work. We then augment this weight in three ways.

First, we account for respondent attrition between consecutive monthly surveys: namely, the differential likelihood that a CPS respondent in the first or fifth survey month will respond to the next three monthly surveys and thus enter our sample. The IPUMS-created survey weights that account for this attrition, LNKFWMIS14WT and LNKFWMIS58WT, are both based on WTFINL. We first create a variable, $w_{i, t}^{0}$, which is equal to LNKFWMIS14WT for respondents in their first set of four consecutive monthly surveys, and equal to LNKFWMIS58WT for respondents in their second set of four consecutive monthly surveys. Next, in order to base this weight on EARNWT, then, we divide this weight by WTFINL and multiply it by EARNWT. Formally, we define our new attrition-based weight $w_{i, t}^{1}$ for respondent $i$ at time $t$ as follows:

$$
w_{i, t}^{1}=\frac{w_{i, t}^{0} * E A R N W T}{W T F I N L} .
$$

Second, we sequentially account for the differential likelihood that CPS respondents in the labor force will a) be employed for four consecutive months, b) be employed at the same job for four consecutive months, and c) additionally not report that they missed work or worked part-time during any of the reference weeks pertaining for the four consecutive survey months for what the CPS terms 'non-economic reasons': performing kin care or other family obligations, having an illness or medical limitation, taking maternity / paternity leave, attending school or training, performing civic or military duty, or taking time off for holiday or vacation. This weighting accounts for any correlation that could exist between a worker's propensity to experience work hour volatility and their propensity to become unemployed, switch between jobs, and/or miss some work for "noneconomic reasons' during a survey reference week.

We account for the propensity of workers to experience work hour volatility using categorical model controls: wage quartile, educational attainment, sex, age, race, marital status, the number of household children, union coverage, and the broad occupational and industry categories listed in Appendix A. Let $x_{i, t}$ be a vector of these characteristics for respondent $i$. Then, we create $w_{i, t}^{2}$, the weight for CPS respondents who remain in the sample after the above restrictions (which we term "sample restrictions"), as follows:

$$
w_{i, t}^{2}=w_{i, t}^{1} \prod_{n=1}^{N} \frac{\operatorname{Pr}\left(x_{t}^{n}=x_{i, t}^{n} \mid \text { In labor force }\right)}{\operatorname{Pr}\left(x_{t}^{n}=x_{i, t}^{n} \mid \text { Under sample restrictions }\right)},
$$

where the probabilities in the numerator and denominator of the above expression are both weighted based on $w_{i, t}^{0}$. This procedure gives more weight to respondents whose attributes for the model variables are less common under this sample restriction than among all those in the labor force.

Third, we augment $w_{i, t}^{2}$ for the likelihood that a CPS respondent will self-report their labor force information in all four consecutive monthly surveys. Let $S R_{i}$ be an indicator variable equal to 1 if respondent $i$ self-reports their labor force information in four consecutive months and 0 if not. We 
estimate this final weight that accounts for respondent self-response, $w_{i, t}^{3}$, in two steps. First, we estimate a probit regression (using $w_{i, t}^{2}$ as regression weights) to predict $S R_{i}$ as a function of the categorical model controls above:

$$
\operatorname{Pr}\left(S R_{i}=1\right)=\Phi\left(x_{i}^{T} \beta\right) .
$$

Then, we create our final weight $w_{i, t}^{3}$ by dividing $w_{i, t}^{2}$ by the predicted probability of self-reporting labor force information in all four monthly surveys:

$$
w_{i, t}^{3}=\frac{w_{i, t}^{2}}{\operatorname{Pr}\left(S R_{i}=1\right)} .
$$




\section{Appendix C: Creating Figures 2 and 3}

Figures 2 and 3 show trends (by wage quartile and educational attainment, respectively) in intrayear work hour volatility from 1995 to 2017, scaled so the mean work hour volatility in 1996 is equal to 100. Because reports of how many hours a respondent worked in the month's reference week systematically vary by month, we seasonally adjust these time series as follows. First, we apply a log transformation to the time series and calculate the difference between each month's logged time series value and the 12-month moving average of the logged time series. Next, we calculate the average difference across years for each month, which gives a seasonal factor associated with each month. Finally, we adjust each month's logged time series value by that month's seasonal factor and then exponentiate the time series to return the seasonally adjusted time series to its original units. We then smooth these seasonally adjusted trend lines with an Epanechnikov kernel with bandwidth equal to six months. 